\title{
Movimentos de Teorizações em Educação Matemática
}

\author{
Theorization Movements in Mathematics Education
}

\author{
João Ricardo Viola dos Santos* \\ Romulo Campos Lins ${ }^{* *}$
}

\begin{abstract}
Resumo
Neste ensaio apresentamos uma discussão de um processo de teorização em Educação Matemática. Na primeira parte, construímos um movimento de teorização a respeito da formação matemática de futuros professores de Matemática, por meio da textualização de uma entrevista. Esse movimento se constitui como resultado de um relato sistematizado de uma experiência, um exemplo exemplar para nossas discussões, bem como um pano de fundo para os delineamentos que realizamos na segunda parte. Nesta, esboçamos algumas ideias de uma Educação Matemática que falamos e nossas atitudes teórico-metodológicas, o Modelo dos Campos Semânticos e a História Oral, que sustentam e dão forma a esse processo de teorização. Tecemos algumas características a respeito de uma estética de pesquisa em Educação Matemática no que se refere ao processo de teorizar.
\end{abstract}

Palavras-chave: Estética de Pesquisa. Formação de Professores. Modelo dos Campos Semânticos.

\begin{abstract}
In this essay, we show a discussion about a process of theorization in Mathematics Education. In the first part, by means of an interview textualization, we elaborated a theorization movement about mathematical preparation of prospective mathematics teachers. This movement is a result of a systematized narrative of an experience, an exemplary example to our discussions and a backdrop to our arguments at the second. In the second part, we outlined some ideas about the Mathematics Education that we talk and our theory-methodological attitudes, the Model of Semantic Fields and the Oral History, which sustain and shape this process of theorization. We point out some characteristics about an aesthetic of research in Mathematics Education regarding the process of theorization.
\end{abstract}

Key-Words: Aesthetic of Research. Mathematics Teacher Education. Model of Semantic Fields.

\section{Parte 1}

Em primeiro lugar, ao se tratar de uma formação matemática sólida do professor de Matemática, penso que ele precisa ter confiança matemática, ou seja, não fugir de situações

\footnotetext{
Doutor em Educação Matemática pela Universidade Estadual Paulista (UNESP). Professor Adjunto do Instituto de Matemática e do Programa de Pós Graduação em Educação Matemática da Universidade Federal de Mato Grosso do Sul, Campo Grande/MS. Endereço para correspondência: Av. Costa e Silva, s/n, Bairro Cidade Universitária, Campo Grande/MS, Brasil, CEP: 79070-900. E-mail: joao.santos@ufms.br

** Doutor em Educação Matemática pela University of Notthingam, Notthingam, Inglaterra. Professor Livre docente do Departamento de Educação Matemática e do Programa de Pós Graduação em Educação Matemática da Universidade Estadual Paulista (UNESP), campus de Rio Claro/SP. Endereço para correspondência: Av. $24-$ A, no . 1515, Bairro Bela Vista, Rio Claro, SP, Brasil, CEP: 13506-900. E-mail: romlins@ @rc.unesp.br
} 
que envolvam Matemática. Podem ser problemas matemáticos puros, situações matematizadas, modelos, pode ser o que for... Tipicamente eu diria que professores do primeiro ao quinto ano do Ensino Fundamental não têm essa confiança matemática. Para ter essa confiança, você não precisa saber muitos conteúdos matemáticos. Você pode ser confiante com a Matemática que você conhece e se você não conhece, apenas diz: não conheço. Mas se você acha que dá para lidar com uma situação, então você não vai fugir, você não vai fugir no sentido de considerar que é uma coisa natural. Você pode tentar e não conseguir, pode tentar novamente e eventualmente não conseguir. Eu poderia comparar confiança matemática, por exemplo, com uma pessoa que tem confiança para dançar. Isso não quer dizer que ela sabe dançar balé clássico no nível do Baryshnikov, ou que ela saiba todos os passos de dança de salão... Quer dizer que aquilo que ela sabe dançar, ela faz confiantemente. Essa seria a primeira coisa.

A segunda coisa, eu chamaria de maturidade matemática que tem relação com a experiência matemática da pessoa, ou seja, um repertório de experiências que faz com que ela se sinta em condições de procurar possibilidades para lidar com situações matemáticas, mesmo quando ela não conhece. Maturidade no sentindo de ter a capacidade de suportar frustração matemática de não conseguir resolver um problema. Eu penso que isso tem muita relação com a experiência que a pessoa tem.

Em relação ao repertório, eu acho que tem relação com conteúdo. Ele é importante na medida de, por exemplo, dizer que uma pessoa que conhece 3000 resultados, teoremas que ele pode utilizar, não está, em princípio, em situação pior do que se ele conhecesse 30 resultados, teoremas. Em princípio, pois pode ser que não seja melhor. Algumas pessoas podem dizer que é melhor conhecer 30 teoremas importantes do que 3000 idiotas. Eu acho que repertório é uma coisa interessante e que a pessoa adquire com o tempo e com as experiências. Assim, formação sólida em matemática é isso.

Eu acho que essas são três âncoras valem também para o matemático. Em geral, penso que dizer que uma pessoa tem uma formação sólida em Matemática, passe por aí. Agora, ao pensar em possibilidades para os professores de Matemática (em formação ou em serviço) desenvolverem essa formação sólida em Matemática, baseado nessas três ancoras que coloquei, confiança, maturidade e repertório, tenho dito, ultimamente, que é um jogo de adivinhação. Não adianta querer dizer isso, aquilo, aquilo outro... porque dessa maneira você pode fazer listas infindáveis de possibilidades. Eu não sei se elas representam muito, porque a formação vai acontecer em um contexto real e dessa maneira, pode ser que uma parte dela dê essa formação sólida para os professores. O futuro professor pode desenvolver essa formação 
fazendo uma série de cursos bem tradicionais de aula expositiva. Pode, por conta própria, estudar e resolver todos exercícios de livros de problemas. Pode, inclusive, desenvolver-se no contexto de um cursinho. Pode desenvolver-se após anos e anos dando aula e tendo que preparar listas de exercícios, provas, ter que corrigir exercícios dos livros. Pode ser que seja um ou outro professor que mostrou, por exemplo, certo entusiasmo e com isso contaminou a turma, pois é muito comum um professor entusiasmado que consegue contagiar os alunos. Essa possibilidade, eu penso, existe em todas as áreas, por exemplo, se você tiver um professor de música que é um grande entusiasta de música, que fala com entusiasmo, que te mostra isso com a própria vida, com a música que toca. Pode ser um ou mais professores que, deliberadamente, criaram um curso de Matemática que deram essas oportunidades, cursos de conteúdo, que eu costumo chamar de meta conteúdo, que seria, ao longo de um curso de conteúdo (que pode ser preparado de mil maneiras, inclusive expositivamente) o professor parasse, virasse outra pessoa e comentasse sobre o que está acontecendo. Por exemplo, o professor poderia falar: 'olha aqui pessoal vocês viram o que está acontecendo, o aluno $A$ falou tal coisa, o aluno $B$ falou outra coisa no que resultou em um certo mal estar, bem estar...'

Falando de maturidade e repertório, que dependem de experiência, deliberadamente eu penso que os formadores deveriam oportunizar uma variedade de experiências - isso valeria para o professor de sala de aula também. Por exemplo, trabalhar com problemas no sentido do Pólya $^{1}$, ou dos americanos dos anos 80 (Edward Silver ${ }^{2}$, Frank Lester $\left.{ }^{3}\right)$, ou das investigações como os ingleses fazem, ou de realizar e trabalhar com modelagem, ou de pedir para os alunos prepararem aulas expositivas para apresentar para o professor e a turma. Por exemplo, no curso de Teoria dos Números que eu estou ministrando na Pós Graduação de Educação Matemática aqui de Rio Claro, eu peço para os alunos estudarem alguns resultados, demonstrações para eles apresentarem. Ontem mesmo, um aluno comentou sobre algumas atividades que envolviam contas, tentativas, atividades meio que 'braçais' e outras em que pedi a eles que estudassem e analisassem um texto. Frente a isso ele me perguntou: 'se a primeira atividade era em uma abordagem construtivista e se a outra não'. Eu falei a ele que não, pois enquanto eles estavam estudando aquele texto, minha intenção era que eles aprendessem e aquilo era tão construtivista quanto às atividades que eles estavam fazendo.

\footnotetext{
${ }^{1}$ George Polya foi um matemático húngaro (1887 - 1985). Escreveu o livro A arte de resolver problemas que é conhecido em todo mundo. É considerado um dos precursores dessa metodologia para o ensino de Matemática.

${ }^{2}$ Frank Lester é um pesquisador estadudinense da Universidade de Indiana, especialista em resolução de problemas.

${ }^{3}$ Edward Silver é um pesquisador estadudinense da Universidade de Michigan, especialista em resolução de problemas.
} 
Eu penso que é importante oportunizar experiências variadas: Matemática experimental, Matemática dedutiva, conhecer estilos de escrita matemática, possibilidades de escrita mais formal, menos formal, recursos diversos... Uma coisa interessante que penso é apresentar mais de uma demonstração para teoremas centrais. Eu acho que isso é experiência. As experiências também precisam ser prazerosas, pois se não forem, os alunos têm a tendência de ir apagando. Se eu tenho a intenção de que o cara tenha experiência matemática e desenvolva um repertório, é nessa direção que eu vou trabalhar e isso, não quer dizer que eu vou ter que escolher uma abordagem. Pelo contrário, vou ter que diversificar, passar por várias abordagens.

No caso da confiança, se o cara tem trauma... eu conheci um professor que dizia para seus alunos: 'do jeito que vocês estão indo, vão acabar cortando cano'. Eu acho que coisas dessa ordem já requerem um olhar psicanalítico, no sentido de uma psicanálise que não pode ser feita pelo formador, com certeza. O que se pode fazer é dar oportunidade e mostrar que não precisa ser traumático, mesmo quando você não consegue alcançar uma solução, não consegue ir longe no problema. É possível fazer aquilo sem dor. Tem gente que acha que é igual musculação, que sem dor não tem resultado, no pain, no gain. Eu conheço uma psicóloga que diz que esse negócio da educação ser prazerosa não existe e que toda aprendizagem envolve dor. Certamente o que eu garanto é que nem toda experiência envolve dor. Eu acho que formação sólida é isso e não está ligada a algum conteúdo. Na verdade, quanto mais áreas você conhecer, dentro da Matemática, melhor será para você. Um modo de dizer isso é falar em ter uma erudição, no sentido de você ter um conhecimento não só aprofundado, mas também lateral e horizontal. Isso me parece uma coisa óbvia de se pensar, que mal não vai fazer. Em princípio, pois pode acontecer, por exemplo, de um professor acreditar que, pelo fato de ele ter todo esse conhecimento, ele é bom demais para seus alunos e isso pode transformá-lo em um professor um pouco estranho. As escolhas também dependem das disponibilidades de tempo, porque certamente não dá para você estudar tudo que seria possível um licenciando estudar. Então, o formador ou o planejador da formação teria que fazer escolhas de áreas que devem ser tratadas e escolhas dentro dessas áreas. Nesse sentido vem o problema: escolhida uma área da Matemática do matemático, até que ponto se vai nessa área? Em relação a isso, minha opinião é que ninguém sabe e ninguém está pensando sobre isso. Mesmo em um curso tradicional da Licenciatura em Matemática, por exemplo, Análise, até onde eu vou com essa disciplina? Imagina que é um curso que vai falar do básico, corpo ordenado dos reais... No meio do caminho eu tenho possibilidades de escolha: coloco isso e não coloco aquilo, demonstro esse teorema, deixo aquele como 
exercício, acrescento isso, tiro aquilo. Mas até onde eu vou? Até onde vale a pena ir pensando que estou oferecendo uma experiência matemática para o professor? Tudo que existe nesse sentido são apenas palpites, tudo relacionado a gosto pessoal, ou então falas do tipo: 'Eu tenho 40 anos de magistério no Ensino Superior, então eu sei’. E isso para mim é a mesma coisa que dizer: minha opinião é... Outra coisa é você escolher a grade de temas matemáticos. Por exemplo, aqui no curso de Matemática da UNESP-RC, eu sinto falta de uma disciplina chamada Matemática Discreta, porque acho, em primeiro lugar, que ela se relaciona bem com coisas da escola e, em segundo, porque ela tem aplicações em profissões, na vida. Já existiu aqui essa disciplina, ela se chamava Matemática Finita.

A escolha das disciplinas no curso de Licenciatura em Matemática é uma questão idiossincrática. A gente pode olhar as diretrizes e ver o que é o básico e que deve ter. Por que o básico é Cálculo Diferencial Integral, Geometria Analítica, Álgebra Linear, Princípios de Análise, Álgebra, Geometria? Porque isso é pegar o que o cara vai aprender em uma sequência conservadora e tradicional e tomar apenas os primeiros passos. Aí tem gente que diz que precisa colocar uma disciplina de Equações Diferenciais. Por quê? Porque o cara está pensando em uma porta para os alunos irem para a Matemática aplicada. Da mesma maneira, que o pessoal da Probabilidade e Estatística quer mudar a disciplina do último ano para o terceiro, para que os alunos, tendo um contato antes, possam fazer iniciação científica nessa área com eles. Ou seja, os caras querem mudar as disciplinas, mas não para ter uma importância em relação às outras disciplinas, o que seria uma coisa cabível. Eles querem mudar por interesses próprios. Por exemplo, ter um curso de Probabilidade antes de ter um curso de Teoria dos Números, ou concomitantemente, seria interessante, pois tem coisas em Teoria dos Números que você faz via Probabilidade. Mas o que acontece é que eles querem fazer essas mudanças para poder garimpar alunos para iniciação científica. Então, esse tipo de fator acaba dominando, pois em um departamento tem um professor que trabalha com, por exemplo, Topologia e, assim, ele quer colocar essa disciplina na graduação. Essas escolhas são complicadas, pois eu não acho que existam critérios que nos ajudasse a ter uma visão clara. Fora que depende do corpo docente que você tem nos cursos de Licenciaturas. Isso é uma coisa que o Marcelo Batarce ${ }^{4}$ já fala faz tempo 'no sentido que um curso de Licenciatura só pode ser feito levando-se em conta onde você está, pois não adianta você colocar um projeto geral que os caras não conseguem executar'.

\footnotetext{
${ }^{4}$ Marcelo Batarce é um educador matemático que atualmente trabalha na Universidade Estadual de Mato Grosso do Sul, no campus de Dourados.
} 
Por exemplo, se eu tivesse que contratar um professor de Matemática que tivesse essa formação sólida, eu olharia para um cara que me convença que ele goste de Matemática. Não para, necessariamente, passar a noite inteira resolvendo um problema, mas que goste de Matemática. Olharia para o cara que goste de estudar um problema de Matemática, mesmo não estando relacionado ao curso que ele está fazendo no momento, um problema, por exemplo, que ele viu na sala do café. Para mim, o cara que só fala de Matemática porque vai ensinar Matemática é esquisito. Olharia também se o cara é um bom resolvedor de problemas, se conversa sobre problemas e discute comigo algumas estratégias, maneiras de interpretar. Um cara que tenha essa certa fluência em problemas matemáticos. Provavelmente também olharia se esse cara tem uma cultura geral que vai além disso, se ele conversa sensatamente sobre coisas, como por exemplo, literatura, música... Um professor que não tem uma cultura geral é uma coisa meio triste. Estou pensando essas coisas no pacote como um todo, na formação de maneira geral e não apenas na solidez, formação sólida em Matemática. Se eu conviver durante um ano com um professor de Matemática e nunca ver esse cara colocar um problema envolvendo Matemática, ou quando colocaram, o cara nunca parou para ler, eu vou ter suspeita sobre a formação sólida desse cara. Isso porque sua ação pode ser uma espécie de não gosto, o que eu acho muito estranho, considerando que o cara é um professor de Matemática. Também pode ser uma forma de se esconder, porque você se expõe. Mas é difícil você saber isso.

Eu acho que os professores deveriam ter cultura geral, ter entusiasmo pelo assunto que vão ensinar e deveriam ter uma certa fluência, que tem a ver com a experiência, repertório, falando dessa solidez. Existem outras características que entram no meio disso e que podem afetar o exercício da profissão, como, por exemplo, a pessoa não gostar de criança, não gostar do barulho de criança. É complicado uma pessoa assim dar aula para a quinta série do Ensino Fundamental.

Pensando a formação de professores de uma maneira geral, o professor precisa ter uma visão sólida de conhecimentos sobre conhecimento, sobre desenvolvimento intelectual, sobre como as pessoas pensam. Precisa de uma capacidade boa de gerenciar grupos, pois o professor é, ou deveria ser, um líder dentro da sala, líder organizacional mesmo. Mas, claro, isso sem detalhar muito. Falo de uma formação sólida em Matemática, uma formação sólida cultural, mas eu não gostaria que parecesse que sem essas coisas não pudesse ter um bom professor. Seria muito bom se ele tivesse todas essas características, mas se ele não tiver, ele ainda pode ser um bom professor. Isso não é uma condição necessária e nem mesmo suficiente, pois se fosse suficiente, eu poderia dizer que seria capaz de descrever o que é ser 
um bom professor de Matemática. Talvez você tenha alguns requisitos mínimos, como um interesse genuíno pelo aluno, um entusiasmo genuíno pelo que ele faz, um interesse pelas coisas que ele vai trabalhar, discutir, propor com as crianças. Uma vez eu estava em um simpósio, com colegas de vários países e cada um ia lá e apresentava uma lista do que um bom professor deveria ter. Eram listas gigantescas com várias características. No painel de encerramento, eu falei (e deixei claro que de maneira alguma eu gostaria de parecer juiz de alguma coisa, pois eu sei que cada um dos que apresentaram tinha pensado por muito tempo) que a gente corre o risco com essas listas de acabar convencendo as pessoas que o bom professor é um SUPER PROFESSOR, é um cara que não existe. De todas as características, atributos de um bom professor que foram apresentados, muitos certamente eu não tenho e assim, certamente, não poderia ser chamado de bom professor. E eu acho que sou um bom professor, por motivos diferentes dos considerados por outros como necessário a um bom professor. Eu acho que eu fui um bom professor desde o começo, pois basicamente eu tinha esse interesse genuíno pelos alunos. Eu tinha acabado de entrar na Licenciatura e comecei dar aulas. Errei muitas vezes, como erro até hoje... Por exemplo, no semestre passado eu dei um curso no qual eu tomei uma postura errada. Conversando com uma das alunas, ela me disse que eu deveria ter dado aula expositiva desde o começo. Os alunos esperavam isso de certa maneira porque eles estavam acostumados, porém, eles não tiveram coragem de dizer. Para você ver, a aula expositiva era a minha melhor alternativa. No início da minha carreira, eu dava aula e tinha uma pessoa comigo que discutia todo dia as coisas que eu fazia. Eu acho que isso é muito importante: o desenvolvimento profissional em um ambiente coletivo. O que está se desenvolvendo não é uma pessoa, mas é o ambiente, um conjunto de ideias com pessoas discordando, concordando, errando, propondo. Eu acho que isso foi o que tive de mais significativo na minha formação e talvez, esse seja o aspecto mais importante para você chegar a ter bons professores em um ambiente trabalhando. Penso que isso também se estende para formadores de professores.

Na Matemática do professor de Matemática, do jeito que sempre falei, são aceitos significados não matemáticos para a Matemática ${ }^{5}$. Isso quer dizer que o professor é capaz de aceitar como legítimos certos modos de produzir significados, que, no caso da Matemática do matemático, você não diz. Um exemplo seria o que aconteceu outro dia na minha sala de aula, quando um aluno disse: 'a vírgula andou duas casas para a direita'. A vírgula não anda. 'Na

\footnotetext{
${ }^{5}$ Para mais informações, consultar o artigo de Romulo Lins: Characterizing the mathematics of the mathematics teacher from the point of view of meaning production. In: 10th International Congress on Mathematical Education, Copenhagen, 2004. Copenhagen. Proceedings... Plenary and Regular Lectures, 2006, p. 1-16.
} 
medida em que o $x$ se move sobre a reta em direção ao ponto $2^{\prime}$. O $x$ não se move. Entretanto, essas são coisas que você aceita tanto num acordo do tipo 'você diria, eu diria', como também num acordo do tipo 'você diria e eu não diria, mas eu consigo imaginar um modo de produzir significado em que eu consiga aceitar que para você, sejam legítimas todas essas coisas'. A Deborah Ball ${ }^{6}$ apresenta um exemplo em que para comparar dois números, você tira a vírgula. Vírgula você não tira. Matematicamente, você construiria um número que, dado um número $x$, vai ser 10 vezes elevado a alguma coisa vezes $x$, isso é 'tirar a vírgula'.

Essa Matemática é natural na escola e também natural na rua, porque ela fala muito de procedimentos sem se importar com definições precisas e com termos que eu já defini e demonstrei. Esse é um buraco muito grande, pois você faz cursos de Matemática (que podemos chamar de cursos de Matemática formal) na faculdade, nos quais você tem uma dinâmica de trabalho específica, enquanto na escola as coisas não funcionam desse jeito. $\mathrm{Na}$ tese da Patrícia Linardi ${ }^{7}$, por exemplo, a pessoa até aprende a lidar com a Matemática do matemático, mas não a utiliza para organizar a sua prática profissional. Nesse ponto a gente fala que a formação matemática do professor precisaria discutir essas coisas, discutir a produção de significados; precisaria chamar atenção para o fato de que na 'hora h' na Matemática do matemático, a vírgula não anda. Entretanto, as pessoas fazem isso, e o que isso quer dizer? Os licenciandos ficaram com isso na cabeça. Quando eles forem falar com seus alunos, não irão se recontextualizar na direção de pensar que tudo bem que eu esteja pensando em multiplicar por 100 para a vírgula andar duas casas para a direita. Por exemplo, se quero transformar uma dízima com período 21 em uma fração, não vou falar que multiplico porque o 0,212121 é 21 vezes $10^{-1}, 21$ vezes $10^{-2} \ldots$ E se eu multiplicar por $10 x^{2}$ esse vai ser o número tal... Eu digo para meus alunos, explicitamente, que nós vamos discutir uma ideia com a qual a gente trabalha sem dificuldade, mas nunca tentou problematizar. Isso é uma discussão histórica que os caras tinham com a Matemática, por exemplo, em boa parte no século XIX. Os matemáticos faziam conta com os números negativos à vontade, sem problema algum causado pelo fato de acharem 'uma quantidade menor que zero'; eles não estavam nem aí. Essas coisas eram perguntadas por outras pessoas, mas para o matemático, ele usava. Mas alguém resolveu responder essas outras perguntas e foi lá que fizeram uma construção do conjunto dos números inteiros a partir do conjunto dos números naturais. Por que não foram fazer primeiro uma construção dos números naturais? Porque os naturais são, como o nome já

\footnotetext{
${ }^{6}$ Deborah Ball é uma educadora matemática estadudinense da Universidade de Michingan.

${ }^{7}$ Para mais informações consultar a tese de doutorado de Patrícia Linardi: Rastros da formação Matemática na prática profissional do professor de matemática. 2006. Tese (Doutorado em Educação Matemática) - Instituto de Geociências e Ciências Exatas, Universidade Estadual Paulista, Rio Claro, 2006.
} 
diz naturais. Contar é contar, você conta coisas, conta coisas que estão lá e não coisas que estão faltando. As operações são definidas a partir de modelos físicos sem problemas. Depois de um tempo, os matemáticos tiveram essa ideia de reduzir os números naturais a conceitos que não são do domínio do mundo físico e, com isso, foram feitas as construções, como por exemplo, os axiomas de Peano. Eu propus para meus alunos que a gente vivesse mais ou menos esse momento. Já tínhamos os números inteiros caracterizados como uma teoria abstrata, um sistema axiomático. Agora iríamos ampliar para falar de números reais e ver que fazemos contas com os números reais, de modo geral, sem problemas. Então vamos ver de onde vem, porque eu posso falar e fazer essas coisas... Essa é uma ideia de tentar reduzir, por exemplo, as dízimas periódicas às estruturas mãe. O que estou usando? Estou usando ordem? Eu tô usando conceito topológico? Algum conceito de estrutura algébrica? Só que para a gente ver como funcionam esses objetos, que para a gente não tem problema nenhum, temos que falar de dentro da Matemática do matemático. Eu acho que isso é um tipo de experiência interessante para os licenciandos perceberem que nela mesmo tem, pelo menos, duas pessoas diferentes com relação a isso. Foi complicado e está sendo. Como eu te disse, a maioria dos alunos falaram que não acreditam que $0,99999 \ldots=1$. Eu espero que o que a gente está fazendo dê uma prontidão para esse tipo de questão, uma possibilidade de pensar sobre isso.

$\mathrm{Na}$ Licenciatura, os licenciandos cursam disciplinas como Cálculo Diferencial Integral, Geometria, Álgebra Linear, Estruturas Algébricas, Análise Real, entre outras. Como já disse, uma justificativa para esses cursos comporem a grade curricular do futuro professor de Matemática que atuará na Educação Básica é a tradição, primeiro lugar. Em segundo lugar, você imagina o que seria a formação de um matemático que entra na graduação. Você sabe, mais ou menos, o que ele sabe no Ensino Médio, como, por exemplo, trigonometria, geometria analítica plana, cálculo algébrico, funções... Assim, você começa a partir disso e vai até a sua formação avançada, quando se especializar e ser, eventualmente, um matemático. No caso do professor, você faz um corte antes. Então a tradição diz que os primeiros cursos são Cálculo, porque é uma Pré Análise, o que é medir hoje em dia. O livro do Courant ${ }^{8}$ é um livro de Pré Análise, mas o livro do Stuart ${ }^{9}$ não é. Introdução à Álgebra Linear, porque está no começo da escada, nos primeiros degraus. Introdução à Estruturas Algébricas para estudar os inteiros, os reais, os complexos. Análise porque formaliza o que você começou a estudar no Cálculo. Entretanto, não são cursos de Análise nos quais tratem de problemas muito incomuns ou que precisassem, legitimamente, do Cálculo com epsilon e delta para resolver os

\footnotetext{
${ }^{8}$ COURANT, R. Differential and integral calculus, V.1. CIDADE DA EDITORA: John Wiley Professio, 1988.

${ }^{9}$ STEWART, J. Cálculo diferencial e integral. Editora: Thomson, 2007.
} 
problemas. Esses cursos de Análise tratam tudo de um modo geral. Então é a escadinha, a escadinha da tradição. As pessoas decidem: vamos colocar isso, isso, e aquilo... Depois elas têm que arrumar uma explicação, porque elas não podem dizer: 'Eu acho'. Tem gente que fala eu 'acho', ou então trata a questão dizendo: 'ah, você não sabe'. Ou ainda: 'Eu sei e isso aqui é o que tem que ser e acabou'. Mas a maioria procura explicações. Então vêm as duas grandes explicações: uma é a questão do cara aprender o que ele vai ensinar, sendo que isso justificaria Geometria Analítica, o trabalho com funções em Cálculo. No caso do nosso curso aqui da UNESP/RC, a disciplina de Aritmética e Álgebra que é uma revisão do que seria um Ensino Médio. A outra justificativa é que o cara vai conhecer os verdadeiros fundamentos daquilo que ele vai ensinar. Neste último caso, ele precisa de Análise para saber o que, na verdade, são os números reais e os complexos, e também, quando ele trabalha com números infinitos, com a ideia de infinito, por exemplo. Com relação a funções, ele tem uma ideia intuitiva de continuidade, de reta tangente e inclinação. Ele viu essas coisas no Cálculo e depois vai formalizar um conceito que, na verdade, se transforma depois na inclinação da reta tangente como um caso particular. Em Geometria Analítica você generaliza no $\mathrm{R}^{3}$ para poder praticamente justificar os métodos vetoriais, porque no plano você utiliza métodos de geometria euclidiana, geometria básica plana, e com coordenadas, você, praticamente, resolve todos os problemas. Mas no espaço não, porque você não enxerga as posições das coisas. No plano, você enxerga as posições de uma vez só, mas no espaço você só tem ângulos. Por exemplo, trabalhar com projeções no espaço, conceber o que é projetar um vetor em outro, tem uma coisa de visualização. Dependendo de como eu olho para as coisas, elas são bastante diferentes. Você também estuda Estruturas Algébricas para poder falar dos inteiros, dos racionais, supostamente. Então eu acho que o outro lado seria esse, ou seja, que aqui estão os verdadeiros fundamentos do que o professor vai ensinar, então é preciso saber. Essas são as justificativas que eu ouço. São essas duas: para o cara aprender e para ver os verdadeiros fundamentos. Enquanto o cara faz coisas com funções em Cálculo, ele está mais familiarizado. Eu não discordo disso, não é mentira, pois é claro que, na medida em que você trabalha com funções, suas propriedades, você desenvolve uma experiência, uma familiaridade com funções. Entretanto, essa não seria a única maneira. Talvez seja uma, pois você não chama atenção para funções. Parece que você está falando de outras coisas e que, ao mesmo tempo, você está 'praticando' com funções, então eu não acho que isso seja ruim em si. Por outro lado, quando você vai para a Análise, por exemplo, para fundamentar os reais e os complexos, o que acontece é que na escola você não fala daquele jeito. Os números reais não são aquilo. Números reais são alguns exemplos, eles não são uma totalidade. Os inteiros e 
os racionais são, mas os reais não são uma totalidade. Os complexos são uma totalidade apenas no sentido de que eles têm uma forma que dá totalidade para eles e que é distinta, que é $a+b i$. Os reais são 'a', como os racionais e os inteiros, então eles não têm uma forma distinta, eles têm uma qualidade distinta como estrutura. Então eu acho que a coisa começa a perder o sentido.

Se você pegar a Matemática nessa região que eu delimitei, que vai ser a da escola, por exemplo, Geometria Analítica Plana, Geometria Euclidiana, Introdução a Álgebra Linear, o Euler praticava tudo isso com certeza, sem dificuldade. Entretanto, ele não tinha nenhum dos quais hoje são chamados os verdadeiros fundamentos, nenhuma dessas coisas. Isso não impedia que ele tivesse todas aquelas qualidades que a gente falou, e com sobra. Todas, todas. Tem um cara chamado Ed Sandifer ${ }^{10}$, considerado melhor especialista de Euler no momento, que tem dois artigos que fala do Euler como professor, mostrando como ele pensava. Esse cara fala de como o Euler adorava crianças e vivia cercado delas. Assim como o Bach que compunha com os filhos no colo. Um de seus livros de exercício de piano mais clássico é o Anna Magdalena Bach, livro que tem o nome de sua filha e que foi escrito para ela praticar piano. O Euler, apesar da cara de mal humorado na foto clássica, era um cara hiper receptivo, que recebia alunos, pessoas interessadas em estudar Matemática em sua casa; gostava de criança e resolvia problemas que a maioria de nós todos, doutores em Matemática, doutores em Educação Matemática, alunos, mestrandos e doutorandos não começaríamos resolver em um ano. Euler não sabia nada de fundamentos que a gente fala hoje, não sabia nada de um curso de Análise I, um curso de Cálculo. A ideia de Estrutura Algébrica, estrutura abstrata, sem chance; estrutura topológica, absolutamente sem chance. Com isso já foram para o ralo alguns argumentos. Euler errava em algumas coisas, ele utilizava procedimentos que ele não poderia usar; o que justificaria os caras falarem: 'está vendo se ele utilizasse a ideia de limite não teria feito isso com essa série formal, porque ele saberia que essas séries têm tais e tais propriedades e acontece isso, aquilo...' Acontece que a maioria das coisas que ele fazia funcionava bem e, onde não funcionava, batia na trave. Outro ponto é que jamais ele iria trabalhar com séries formais no Ensino Médio, pensando de uma maneira para argumentar no sentido dele, hoje, ser um professor da Educação Básica. Então, em todas as coisas que ele fosse trabalhar, o que aqueles objetos eram para ele, não são as mesmas coisas que esses objetos são, hoje, na Matemática do matemático e isso não tinha a menor importância.

\footnotetext{
${ }^{10}$ Ed Sandifer é um matemático, especialista em Euler, da Universidade de Western Connecticut, no Estados Unidos.
} 
Conclusão: se o Euler tivesse estudado por conta própria, ele seria um excelente professor; eu gostaria de tê-lo como professor dos meus filhos.

Esse argumento desmonta completamente essa mitologia criada em torno do cara ter que fazer essas disciplinas, a ideia da formação do professor como bacharel mais pedagogia. Isso desmonta. Se isso funciona em outro país é uma coisa a se estudar. Funciona? Como funciona? Certamente se funciona não é por uma qualidade intrínseca a essa formação matemática e sim por conta de outras relações. Meu chute é que para o aluno de classe média, alta burguesia, um curso de Matemática escolar tradicional pode ser uma boa base para se desenvolver de maneira criativa, porque ele tem muitas coisas fora da escola onde pode desenvolver uma série de possibilidades, uma série de experiências. $\mathrm{O}$ aluno de classe popular não tem acesso a isso, não tem condições materiais, mesmo porque a sociedade em geral não as oferece. Existem algumas coisas como museu de ciência, ciência na praça, museu da língua portuguesa, ou seja, existem alternativas, mas culturalmente esses alunos não frequentam. Aliás, isso é uma coisa interessante, pois quando começou a ter efeito o Bolsa Família ${ }^{11}$, quando os economistas começaram a identificar que milhões de pessoas saíram da linha da pobreza, criou-se um mercado interno muito mais robusto. O shopping de Rio Claro começou ser frequentado de maneira abismal, chegava sábado e entupia de gente andando de modo de não ter para onde ir. Vendo isso me ocorreu uma coisa interessante, pois as lojas não estavam cheias. Ocorreu-me de pensar que as pessoas não fossem nesses lugares porque não tinham roupa. Agora o cara tem uma bermuda maneira, um tênis, uma ou duas camisetas. Esse cara, que não frequentava o shopping, agora vai. A mesma coisa pode ser que aconteça com o museu. Se um mendigo tentar entrar no $\mathrm{MASP}^{12}$, em São Paulo, é provável que a segurança não o deixe entrar. Se o mesmo cara for lá e fazer a barba, colocar uma calça jeans e uma camiseta, ele entra. Esse exemplo é uma questão radical, mas deve ter uma escala que o próprio cara se policia para não entrar. Pode ser que, na questão da formação do professor, isso funcione igual para o aluno. Se um grupo de professores tiver um capital cultural, contribuindo com uma literatura, uma experiência, tendo coragem de inventar coisas para a sala de aula, para experimentar, talvez isso seja essencial, no sentido de pensar a escola pública, ou uma estratégia que beneficiasse trabalhar a formação coletivamente.

\footnotetext{
${ }^{11}$ O Bolsa Família é um programa de transferência direta de renda com condicionalidades, que beneficia famílias em situação de pobreza ou de extrema pobreza. O Programa integra o Fome Zero que tem como objetivo assegurar o direito humano à alimentação adequada, promovendo a segurança alimentar e nutricional e contribuindo para a conquista da cidadania pela população mais vulnerável à fome. Esse programa teve início no ano de 2003.

${ }^{12}$ Museu de Arte de São Paulo.
} 
Então, para mim, essas disciplinas que falei, certamente, não são necessárias e certamente elas não são suficientes. Entretanto, eu vejo algumas possibilidades para discussão dessas disciplinas na Licenciatura. $\mathrm{O}$ que eu faço como professor, quando ministro uma disciplina de Matemática para professor ou educador matemático, é usá-la para trabalhar as ideias de estranhamento, descentramento e diferença. Eu tento colocar o aluno da graduação frente a uma situação que é estranha a ele, estranha no sentido, por exemplo, os números inteiros são classes de equivalências de pares ordenados de naturais. Isso é o que os números inteiros são. O cara olha e, evidentemente, aquilo não é os inteiros para ele. Eu sei que isso não é os inteiros para eles, pois, para eles, os inteiros são $-1,-2,-3 \ldots$ Eu falo: 'vocês viram, nós definimos'. Vocês viram que nós definimos no começo do curso. Às vezes, eles falam: 'os axiomas podem mudar'. Eu digo: 'mas mudar os axiomas quer dizer criar uma estrutura nova e não que essa outra vai desaparecer'. Eu vou continuar tendo uma estrutura e continuar chamando de inteiros. Depois eu posso ter uma outra construção que torne as coisas mais próximas, por exemplo, construir com a ideia de flechinha. À medida que eles reconhecem que existem coisas que devém do que é e, simplesmente devém, pelo fato de que eu não digo a eles que aquilo é diferente (até porque estou dizendo que é a mesma coisa), mas porque para eles, não pode ser a mesma coisa (nesse caso, os números inteiros), tem-se o estranhamento, ou seja, você se vê em uma posição que você não consegue dar conta, e não consegue aceitar.

O descentramento é o processo pelo qual você tenta mudar de lugar no mundo, mudar de interlocutor. Na linguagem do Modelo dos Campos Semânticos ${ }^{13}$ seria falar em outra direção para ver se existe alguma, na qual aquelas coisas são legítimas, ou seja, que elas podem ser ditas. $\mathrm{O}$ cara tenta se colocar como um outro que escreveu aquilo achando que aquilo poderia ser dito. Então o descentramento é mudar o centro, é você sair de você como centro e tentar ir para o lugar onde o outro está como centro. Nisso aparece a questão da diferença, ou seja, o que eu vou fazer com isso? Uma resposta seria mudar o modo de produção de significado. Essa diferença toda é formativa, pois quando o futuro professor estiver na frente do seu aluno, ele pode imaginar o estranhamento e sua possível negação, pois

\footnotetext{
${ }^{13}$ Para mais informações a respeito do Modelo dos Campos Semânticos, consultar os seguintes textos de Romulo Lins: Perspectivas em aritmética e álgebra para o século XXI. Campinas: Papirus, 1997 [em coautoria com Joaquim Jimenez]; Por que discutir Teoria do Conhecimento é relevante para a Educação Matemática. In: BICUDO, M. A. V. (Org.). Pesquisa em Educação Matemática: Concepções e Perspectivas. Rio Claro: Editora UNESP, 1999. p. 75 - 94; The production of meaning for Algebra: a perspective based on a Theoreticall Model of Semantic Fields. In: SUTHERLAND, R. et al. Perspectives on School Algebra. Netherlands: Kluwer Academic Publishers, 2001. p. 37-60; O modelo dos campos semânticos: estabelecimentos e notas de teorizações. In: Claudia Laus Angelo, et al. (Org.). Modelo dos Campos Semânticos e Educação Matemática: 20 anos de história. São Paulo: Midiograf, 2012, v. 1, p. 10-20.
} 
negá-lo é uma possibilidade. Se você ler o texto do Bourbaki ${ }^{14}$ e achar contraditório, tem duas coisas que você pode fazer: a primeira é rasgar o texto; a segunda é tentar o descentramento. Esta é uma atitude mais interessante, sendo que nisso vêm a questão da diferença. Sempre digo para os meus alunos, futuros professores, que eles nunca se esqueçam que pode estar acontecendo um estranhamento com seus alunos quando estiverem ministrando aulas. É interessante que o estranhamento tem que incomodar aqui na barriga, como a história do Baudelaire, da racionalidade e da sedução, ou seja, o estranhamento não é um incômodo no plano das coisas que você pode falar, por exemplo, 'eu não gosto disso', ou, por exemplo, 'número inteiro não é isso'. Eu não quero que ele se incomode nesse plano. Quero que o incômodo seja ao ponto de causar uma náusea, uma náusea sartreana, existencial.

Poderia ter outros contextos nos quais os futuros professores pudessem experienciar o estranhamento, descentramento e a diferença. Entretanto, eu argumento, com base nas coisas que eu escrevi utilizando teoria dos monstros ${ }^{15}$, que como a Matemática do matemático não é desse mundo, ela permite você colocar o cara na frente de situações que confrontam o senso comum das pessoas normais, pessoas do cotidiano, do mundo físico. A ficção, por exemplo, seria um desses contextos, sendo que também a Matemática do matemático, em um certo sentido, é uma obra de ficção inspirada em fatos reais, segundo o próprio Bourbaki. As estruturas abstratas são inspiradas em fatos reais, sendo que fatos reais são as teorias particulares. Mas é uma obra de ficção mesmo porque o cara inventa, ele diz: 'isso é um grupo'... Alguém pode dizer que é um pouco no sentido das fábulas que tinha uma ideia de passar uma certa mensagem moral, mas certamente a raposa não fala, e o gato não usa botas, e o chapeuzinho vermelho não tira a avó da barriga do lobo depois que ele a engoliu. Nesse sentido que eu digo, baseado nas teses do que eu comentei naquele trabalho sobre Teoria dos Monstros, que a Matemática do matemático oferece oportunidade imperdível, não sendo único no sentido de que não existe outro, mas é uma chance imperdível, excelente. A gente não pode perder essa chance. Então, eu não tiraria totalmente os cursos de Matemática do matemático da formação do professor, mesmo que eu pudesse fazer um currículo baseado totalmente em outros conceitos.

Veja, por exemplo, esse trecho do texto do Felix Klein de $1908^{16}$

\footnotetext{
${ }^{14} \mathrm{O}$ depoente faz referência específica ao artigo BOURBAKI, N. The Arquitecture Mathematics. Notices of American Mathematical Society. v. 57, n. 4, p. 221-232, 1950.

15 Para mais informações consultar o texto de Romulo Lins: Matemática, monstros, significados e educação matemática. In: BICUDO, M. A. V. \& BORBA, M. C. (Orgs.). Educação Matemática: pesquisa em movimento. São Paulo: Cortez, 2004, p. 92 - 120.

${ }^{16}$ KLEIN, F. Elementary Mathematics from an Advanced Standpoint: Geometry. Mineola: Dover Books, 2004.
} 
[...] Por muito tempo [...] os homens da universidade preocuparam-se exclusivamente com as suas ciências, sem considerarem as necessidades das escolas, nem mesmo se preocupando em estabelecer uma conexão com a Matemática escolar. Qual foi o resultado desta prática? $O$ jovem universitário se encontrava, no início, confrontado com problemas que não sugeriam, de maneira nenhuma, as coisas com as quais ele tinha se ocupado na escola. Ele chegava à Universidade e naturalmente, ele esquecia estas coisas rápida e completamente. Quando, ao fim de seus estudos, ele se tornava um professor, encontrava-se repentinamente na posição de ter que ensinar a tradicional matemática elementar da antiga e pedante maneira; e, uma vez que ele praticamente não era capaz, sem ajuda, de distinguir qualquer conexão entre esta tarefa e sua Matemática universitária, logo se acomodava ao que a tradição honrava, e seus estudos universitários permaneciam apenas uma lembrança mais ou menos agradável, que não tinha nenhuma influência sobre seu ensinar.

Veja também esse texto da Anne Watson, agora de $2008^{17}$

a matemática escolar não é, e talvez nunca será, um subconjunto da reconhecida matemática acadêmica, pois ela tem diferentes justificativas, autoridades, formas de raciocínio, atividades centrais, propósitos e conceitos unificadores e, necessariamente que os recortes da atividade matemática se dão em diferentes maneiras daquelas da matemática acadêmica.

eu entendo a matemática acadêmica por atividades que avançam o conhecimento matemático: as formas de engajamento, tipos de questões, padrões de argumentos que são aceitos como contribuinte para o cânone convencional da matemática pura e aplicada.

Por matemática escolar, ela entende as formas de engajamento na matemática em contextos formais de ensino para o iniciante, incluindo os graduandos, ou por aqueles que não se vêem como iniciantes, mas que tem a matemática impelida sobre eles.

Eu concordo completamente com essas afirmações e acho que o que está colocado é que uma coisa é a ciência matemática e a preparação de pessoas para trabalharem nessa ciência, e a outra coisa é a questão da educação matemática das pessoas, mesmo que você considere em diversos níveis. Eu acho muito difícil, por exemplo, que, em um curso de Pós Graduação em Matemática (com exceções, mas muito pequenas) o cara vai ficar se preocupando com jogos para motivar os alunos, a utilização de material concreto... Ele pode até utilizar computador, até porque se utiliza para fazer Matemática de ponta. Para mim, existe uma Matemática do professor de Matemática, Matemática da Educação Matemática, e a Matemática do matemático. Eu vejo que acontece bem o que o Klein coloca. O tipo de experiência matemática que o cara tem na Licenciatura em Matemática não é o tipo de experiência que o aproxime dos alunos, dos jeitos dos alunos pensarem. Há também outra coisa, essa experiência não é próxima dos jeitos naturais dele pensar. Você não pode perder de vista que o licenciando era aluno até bem pouco tempo atrás. O cara fica na faculdade apenas quatro anos e não muda 18 anos de vida. Esse é um problema que eu considero grave, pois é operacional. A experiência que você tem na graduação não é o tipo da experiência que você gostaria de compartilhar com seu aluno, porque se você for compartilhar esse tipo de

${ }^{17}$ WATSON, A. School Mathematics as a special kind of mathematics. For the Learning of Mathematics. v. 28 , n. 3, p. 3-7, 2008. 
experiência com ele, você vai estar completamente distante dos modos legítimos de produção de significados, dos objetos, das categorias que organizam a vida dos alunos. Então, o que vai acontecer é que você vai ficar falando de coisas que, para eles, em boa parte, são incompreensíveis. Por isso, a gente está estudando a formação matemática do futuro professor de Matemática em torno de categorias do cotidiano ${ }^{18}$, pois quem sabe se ele tivesse experiências (não o tempo todo no sentido de tirar a Matemática do matemático) de trabalhar a partir de categorias do cotidiano, ele teria oportunidades de se aproximar dos seus alunos, a partir da experiência matemática que ele vai propor. Ao mesmo tempo, e isso é que é interessante, a formação do futuro professor na universidade seria feita a partir de categorias que são mais próximas dele enquanto um aluno ingressante na universidade. Assim, ele ganharia essa ideia de categorias do cotidiano, e também a Matemática do matemático, que simplesmente é outra coisa, nem boa nem ruim, a não ser que você considere para que e para quem.

A Matemática do matemático tem seu interesse e tem seu ideário. Nesse sentido eu penso em traduzir o texto do Bourbaki, porque eu acho que tem que circular muito para as pessoas entenderem que não adianta falar mal, não é que o Bourbaki está errado. Essa é a Matemática do Bourbaki, a Matemática do matemático de hoje em dia. Nesse texto, fica claro que a Matemática do matemático é mutável, que é possível criar outras estruturas. Entretanto, ele acredita que você pode falar dela apenas falando dos procedimentos do método axiomático, que você não precisa falar nem do mundo físico e nem das grandes categorias do pensamento.

$\mathrm{Na}$ Inglaterra, para ser professor, você precisa ter uma graduação em qualquer área e fazer um ano de um curso chamado Postgraduate Certification in Education, PGCE e com isso você está apto a ser professor de Matemática. Aparentemente, eles não têm problemas com esse tipo de formação, ou seja, não é tão problemático a formação inicial de professores de Matemática quanto é aqui no Brasil. Primeiro lá é o $3+1$ mais puro que você possa imaginar, pois realmente são três anos relativos a um bacharel, mais um relacionado à pedagogia. O que eu acho que a gente deve considerar é que funciona, e quando eu digo isso é no sentido de pensar que a escola inglesa forma professores e estes vão para a escola e formam pessoas que são, como população em geral, criativas. A Inglaterra é o maior Produto

\footnotetext{
${ }^{18}$ Para mais informações consultar o texto de Romulo Lins: Categories of everyday life as elements organising mathematics teacher education and development projects. In: 15th ICMI Study 'The professional education and development of teachers of mathematics', 2005, Águas de Lindóia, SP; e a tese de doutorado de Viviane Oliveira: Uma leitura sobre formação continuada de professores de matemática fundamentada em uma categoria da vida cotidiana. 2011. Tese (Doutorado em Educação Matemática) - Instituto de Geociências e Ciências Exatas, Universidade Estadual Paulista, Rio Claro. 2011.
} 
Interno Bruto (PIB) per capita de patentes, uma potência científica, tecnológica, e por isso eu penso que deve ser estudado. Quando eu conversei meio informalmente com um colega inglês, ele me disse que existe falta de professor, que a escola não vai bem, porque a Inglaterra está meio que no meio da tabela do PISA ${ }^{19}$. Mas tomando a Inglaterra como um país que precisa produzir ciência e tecnologia, é um país muito bem sucedido. Esses dias eu vi um dado interessante, que eu não lembro bem como ele estava formulado, mas que colocava a Inglaterra no topo das potências científicas, junto com o Estados Unidos, China. Então eu pergunto: como o professor é formado lá? O cara faz um bacharelado junto com todo mundo, as disciplinas são as mesmas de todo mundo, Análise é Análise, Cálculo é Cálculo, não tendo uma diferenciação para quem vai ser professor e se, depois, ele quer ser professor, vai à uma escola de Educação que tem mais um ano de atividade no PGCE. Nesse tempo ele vai à escola e depois sai habilitado a dar aula. A última vez que eu escutei, existia um estágio probatório para o cara que iria para a escola nos primeiros anos. Recentemente, nessa conversa que tive com esse colega inglês, soube que o governo queria que a parte pedagógica não fosse feita na universidade e que fosse feita na escola. Com isso, o cara faria o bacharelado, depois iria para escola, faria a parte pedagógica e teria um acompanhamento. O que é extremamente desafiador é que essa formação que a gente aqui no Brasil diz que não funciona, é a formação adotada pela Inglaterra e pela França, dois exemplos de potências científicas tecnológicas. Eu penso que seria muito interessante investigar a formação de professores de Matemática na Inglaterra. Eu acho que a gente tem muito palpite quando fala que não funciona, pois ninguém nunca foi investigar o que significa funciona ou não funciona. Vou reiterar: nós temos exemplos de países reconhecidos tecnologicamente que adotam exatamente o modelo de formação de professores que a gente fala que não funciona. Não funciona e não se diz para que.

Tem muita gente que propõe esse modelo de formação aqui no Brasil, por exemplo, o Marco Antonio Moreira ${ }^{20}$. Para o professor do Ensino Médio a formação seria um bacharelado mais um mestrado profissional que corresponde totalmente ao PGCE, que é uma Pós Graduação, é um mestrado. No Brasil, tem gente que defende isso. Eu acho que dependendo do projeto que você tem e dependendo do que você espera, esse todo do bacharelado mais complemento vai ter que resultar nisso ou naquilo. A mentalidade de alguns colegas que eu vejo é de que é conteúdo mais uma preparação pedagógica, e outros acham

19 PISA é o Programa Internacional de Avaliação de Estudantes. Para maiores informações consultar: http://www.pisa.oecd.org

${ }^{20}$ Marco Antonio Moreira é professor e pesquisador na Área de Ensino de Ciências. Atua na UFRGS. 
que não. Eu acho que uma outra questão é a formação de professores de $6^{\circ}$ ao $9^{\circ}$ ano do Ensino Fundamental que é, supostamente, diferente da formação de professor do Ensino Médio, pois esta seria mais. Isso foi muito aplicado no Brasil, mas a questão central a ser colocada é a do capital cultural que os alunos têm em casa. Então um professor conteudista que resultaria dessa formação, pode ser um professor adequado se os alunos tivessem esse capital cultural em suas casas, o que iria complementar sua formação.

Você tem exemplos de países onde os professores são formados segundo tudo o que a Educação Matemática brasileira, ligada à formação de professores, diz que não serve, e lá funcionam. Temos quase nada de pesquisas que realmente questionam a formação matemática. Agora funciona, não segundo os exames do PISA e do TIMSS ${ }^{21}$, mas funciona porque é um país funcional, que tem mão de obra bem preparada, criativa, produz patente, produz ciência e transforma ciência em tecnologia.

Existe um índice chamado índice de criatividade curiosamente criado por pessoas que trabalham com marketing, que leva em conta coisas do tipo: produção científica, transformação de ciências em tecnologia e transferência de tecnologia para a indústria. Então não é só se o aluno tira notas boas no PISA. Na verdade é pensar se nesse país se produz ciência e se ela é transformada em tecnologia. Isso é diferente de você ter tecnologia em laboratórios de empresas. A ciência é produzida na universidade sem compromisso com tecnologia e ela é transferida para a tecnologia. A tecnologia que poderia ser produzida também nos laboratórios de empresa, é produzida para indústria e produção. Seria isso entre outras coisas. Eles chamam de índice de criatividade, uma cadeia de coisas. A Inglaterra está no topo, sendo muito valorizada. Parece que esse é um indicador de testes internacionais que não olha para o próprio umbigo. As avaliações, TIMSS, PISA, parecem que são insuficientes porque se você olha para o papel de um sistema educacional em um país, ele certamente não é apenas fazer o cara tirar nota na prova.

No Brasil você fala que os professores são mal preparados, que nos testes os alunos vão mal e um monte de outras coisas, porém o Brasil na escala internacional de Matemática é 2, sendo que o nível 1, que eu saiba, é EUA e Rússia, não sei se recentemente a China reascendeu. Mas o Brasil é nível 2. O que quer dizer que, em termos de produção de Matemática, está em mesmo pé que a França, Alemanha, Itália... O Brasil está em segundo plano em nível internacional, o que o deixa muito bem. Aí a gente fala: 'Poxa a gente tem uma escola ruim, o Brasil vai mal'. Mas o Brasil está mal no critério de inserção ou pontuação

\footnotetext{
${ }^{21}$ Tendências Internacionais do estudo de Matemática e Ciências é uma avaliação internacional de alunos de 910 e 13-14 anos, de alguns países do mundo, nas áreas de Matemática e Ciências.
} 
de produção matemática internacional? Não, porque se você só tem dois países acima, certamente não estamos mal. Poderíamos pensar que o Brasil vai mal em relação de indicadores internacionais de Economia? Não. Aí a gente reclama da nossa escola.

Talvez pudesse pensar que como a Inglaterra tem um sistema de Ensino da Educação Básica de qualidade, no sentido de que os alunos estudam, tem bons desempenhos. Talvez qualquer formação que um futuro professor tenha, por ele já ter essa primeira formação na Educação Básica muito forte, um curso que apresente minimamente oportunidades para eles discutirem algumas coisas sobre Educação e um apoio forte para o professor, isso tudo já daria condições de ele ser um bom professor de Matemática. Agora, vamos supor que a formação dele foi convencional, o que não é verdade na Inglaterra porque a maioria das escolas trabalha com materiais diferenciados. Mas, se esse cara teve uma formação convencional, depois foi para um bacharelado e depois foi fazer uma prática pedagógica, qual é o modelo que esse cara tem? Porque as pessoas agem de acordo com os modelos que elas têm sobre o que deve fazer em sala de aula. Suponha que todos estejam reproduzindo esse modelo e o país como um todo consegue ser produtivo, criativo e assim por diante. Isso me chama atenção. Então, eu acho que não dá para dizer, exatamente, que o problema é a formação. Eu acho que o problema não é o professor, mas sim o sistema como um todo. Eu te dou um exemplo, o colegial, como hoje ele é, forma um cara que não é nada. Ele forma um cara que basicamente e idealmente quer fazer um vestibular e entrar na universidade, mas se ele não entrar na universidade o que sobrou para ele é zero. Nós temos uma escola para a classe média e para a burguesia que tem expectativas para a universidade. Então se o cara não entrar, não temos nada, porque todo mundo vai estudar tudo igual sem especialidade e profissionalidade nenhuma. Na Inglaterra existe muito mais consciência profissional. Então esse é o tipo de parâmetro que deveria ser estudado e não é.

Eu acho que a Inglaterra é um exemplo que aponta o seguinte: a discussão sobre que formação o professor precisa ter não é tão ingênua como se parece fazer parecer. Ela envolve a cultura no sentido mais amplo, um projeto político, pois é um governo que vai colocar diretrizes e, depois, as maneiras de você implantar as políticas. É complexo mesmo e não complicado. Eu diferencio o complexo do complicado. O complicado tem uma origem linguística no plica, a dobra, tanto é que a saia plissada é saia com aquelas dobras. $\mathrm{O}$ complicado então é o que tem dobras que você, eventualmente, pode desdobrar, descomplicar, no sentido que você vai abrindo e chega a um certo ponto em que você vê as coisas desdobradas. Com o complexo você não pode fazer isso, pois não se tratam de dobras que foram feitas, se trata de alguma coisa que é própria daquele assunto e que não tem como você 
desmembrar, desdobrar. A questão da Educação é complexa propriamente e, correspondentemente, a questão da formação do professor, é complexa. Eu acho que um estudo comparativo sobre o que acontece com a Inglaterra, Brasil e França pode revelar possibilidades de relações entre culturas e possibilidades de intervenção. A questão da formação matemática de professores tem sido tratada levianamente, de maneira leve demais, ligeira. Fora que em vários casos tem sido tratada sem imaginação nenhuma.

Pensando em um projeto de Licenciatura em Matemática eu não pensaria na formação Matemática, mas pensaria o tempo inteiro na formação em Educação Matemática. Esse seria o primeiro ponto. Então eu não posso pensar no meu projeto em categorias que eu não considero. O que eu vou fazer é te dar uma ideia do que seria um programa de formação que, desde muito tempo, antes de eu sair para meu doutorado, eu já discutia.

Eu acho que no primeiro ano o futuro professor vai fazer uma espécie de transição para algumas ideias importantes tanto com relação à Matemática quanto com relação à Educação Matemática. Eu acho que deveria ter uma disciplina extensa chamada Seminários de Resolução de Problemas, na qual ele veria, como eu faço com meus alunos em todos os cursos, diferenças entre soluções de problemas. Ele resolveria alguns problemas que fazendo alguns exemplos ele se convence, problemas que tivessem soluções com explicações verbais, problemas em que ele precisasse apresentar uma explicação formalizada. Nessa disciplina, os licenciandos veriam problemas dos tipos do grupo da Dona Lourdes ${ }^{22}$, problemas dos tipos do Polya... Seria um seminário para o cara começar a refletir sobre alguma coisa que ele não fez na vida em geral. Ele começaria a resolver problemas, ver a necessidade da teoria de resultados mais gerais dos quais ele já esteja se utilizando, vai discutir a ideia de derivar resultados mais gerais dos particulares, vai discutir a intenção didática do professor dele que está dando o curso.

Eu acho que deveria ter um Seminário Light (light é a maneira que eu chamo) de História da Matemática, no qual em algum ponto eles deveriam olhar a Matemática a partir do método axiomático, segundo o texto do Bourbaki que eu mencionei. Nesse seminário discutiríamos a questão da historicidade do conhecimento tanto no sentido da história da Matemática, que pode ser ilustrativa, mas também desenvolver um sentido que toda produção matemática é historicamente localizada e isso não se aplica apenas à Matemática, mas a tudo.

22 Dona Lourdes de la Rosa Onuchic é professora e pesquisadora da área de Educação e atua no programa de Pós Graduação de Educação Matemática da Unesp de Rio Claro/SP. Grande parte de seus trabalhos são sobre Resolução de Problemas. É líder do GETERP (Grupo de Estudos e Trabalhos em Resolução de Problemas). 
Eu acho que essa parte da formação tem uma importância excepcional, porque é uma proposta ideológica de você tornar a existência histórica e material.

Teria uma terceira disciplina que o levaria de volta para a escola, não mais como um aluno, mas com um olhar de um quase aluno (até porque ele não está tão distante), para olhar coisas do tipo: a diretora que ele achava que antes era uma repressora, mas agora ele olha como um elemento importante na organização do que acontece na escola. Então esse cara poderia entrar na secretária, olhar o que se faz lá, entre outras coisas. Para mim, esse seria o primeiro ano, esses três grandes pontos.

Depois a coisa multiplica muito e fica muito variada. Poderíamos ter disciplinas matemáticas no sentido que eu mencionei (estranhamento, descentramento e diferença), disciplinas de aprofundamento do que o cara vai ensinar, discussões filosóficas sobre o papel dele no mundo, discussão profissional propriamente dita. Isso se multiplica para os outros anos. A única coisa que eu quero acrescentar é que no Brasil as oportunidades de formação depois que o cara sai da faculdade para dar aulas são muito poucas, infelizmente. Penso que precisaríamos de diretrizes para que as universidades que formam professores tenham obrigações de durante, digamos, cinco anos, oferecer oportunidade de formação dos mais variados tipos para os professores. Eu, pessoalmente, favoreceria oportunidade de discutir o que está acontecendo na sala de aula do professor e oportunidade de discutir propostas para essa sala de aula. Isso seria em algum ponto do curso, segundo, terceiro, quarto ano.

O resto do curso, sinceramente, acredito que poderia ser qualquer coisa, no sentido de se ter muitas alternativas. Quero dizer que as possibilidades nesse 'miolo' são infindáveis, pois o que é essencial, o que o cara precisa, é ter uma experiência matemática diferente da que ele tinha antes.

$\mathrm{Na}$ verdade o que eu vou falar vai soar meio como radical, talvez soe mal. Eu acho que quando a pessoa dissesse 'quero ser professor de Matemática' a gente deveria colocá-la em sala dando aula como regente, não é como observação, é como regente mesmo. A partir disso é que ele iria se desenvolver. Entretanto, o Brasil tem problemas de apoio, de oportunidades, de desenvolvimentos... . Então, em um projeto mais conservador, o licenciando iria para o fim do curso e assumiria a responsabilidade de uma sala de aula, tendo em vista essas reflexões todas que ele fez. O que está no meio do curso, eu não sei o que seria porque poderia ser um trilhão de combinações possíveis e é nesse sentido que eu falei que o que está no meio não tem como definir, não tem como fechar o pacote.

Se eu pensasse em alguma disciplina de Educação Matemática, ou seja, que ele tivesse contato com as pesquisas que tratam da sala de aula no sentido de propostas didáticas, teria 
que ser muito franco e muito desagradável com o que eu vou dizer. Tendo em vista uma quantidade muito grande de estudos em Educação Matemática na academia que eu tenho ouvido falar, eu acho que eles são completamente inúteis, pois são estudos do tipo: 'testar o uso de um jogo $x$ para ensinar um conceito $y$ em um lugar $z$ '. Então, se a gente está falando de conhecer as pesquisas, eu acho que nenhum professor merece, na graduação, enquanto um componente curricular, conhecer essas pesquisas. É claro que se isso estiver disponibilizado e ele tomar contato, eu acho que não tem problemas, mal não faz. Ele vai filtrar as experiências da vida dele de acordo com o que ele quiser na verdade. Eu acho muito complicado tentar definir que experiência eu vou tentar colocar sobre meus alunos nesse miolo. Eu não sei. Idealmente esse curso seria construído ano a ano com um começo e um fim. Teria um começo que seria um seminário de resolução de problemas que pode ser, inclusive, fundido no seminário de história e a volta à escola. Teria um fim de tudo na docência na escola, nas oportunidades de desenvolvimento profissional. Se eu fosse dar todas as disciplinas do primeiro ao quarto ano, só decidiria o que fazer na hora. Voltando ao exemplo em relação ao curso que ministrei de Teorias dos Números, cheguei à conclusão, ao fim de tudo, que eu deveria ter dado aula expositiva do começo ao fim para os alunos, aula expositiva, exercícios e prova. Mas essa é uma decisão que eu só poderia ter tomado no interior do curso e no meu caso, cheguei a essa conclusão, depois que o curso acabou. Então, eu pessoalmente não acho que seja possível você definir a priori. A gente faz isso apenas por praticidade.

Agora, pensar isso em termos de políticas públicas, a coisa complica, miraculosamente, a ponto da multiplicação dos pães e dos peixes. Políticas públicas operam em uma escala que é completamente diferente da escola. A escala do sistema todo é completamente diferente da escala da escola, então eu acredito que quando a gente fala de políticas públicas não se pode jamais referir ao que acontece na escola e, ao mesmo tempo, se estou na escola e penso em parâmetros para a escola, eu jamais posso me referir ao que seria recomendável para um sistema. O que quero dizer com toda essa conversa? São dois planos de existência completamente diferentes. $\mathrm{O}$ que o formulador de políticas públicas espera não pode jamais se confundir com o que o professor ou a escola espera. Não dá para transformar uma coisa em outra.

Em termos de propostas, que poderiam ser feitas e até mesmo levadas para que os formadores dos cursos pudessem implementar alguma estrutura, seria o que eu disse. Você tem um começo e um fim. Idealmente você só tem um começo. Você vai para a sala de aula e a gente vai te oferecer o apoio que puder oferecer. Se o professor tiver dúvida de conteúdo, a 
gente discute conteúdo. Se for dúvida de disciplina, a gente discute disciplina ${ }^{23}$. Idealmente isso é o que oportuniza o professor a exercer bem sua profissão. Eu tive a felicidade de ter isso com o apoio de várias pessoas muito competentes, mas se eu tiver que estruturar algo, acrescentaria mais uma coisa. Pensando que o que importa na formação de professores é a entrada e a saída, no primeiro ano eu acrescentaria um Seminário de Educação Matemática, o que talvez contemple as questões das pesquisas em Educação Matemática. Agora, Física, Cálculo, nada disso... Isso eu conversava com o Seiji ${ }^{24}$, antes de sair para o doutorado. Isso é a experiência que o cara precisa para ser um bom professor de Matemática. Se você comparar com o que eu disse lá atrás é compatível com maturidade, uma certa erudição, cultura geral... A saída é um certo tipo de experiência de regência que é exercida coletivamente. Então prática de ensino é o cara dando aula durante um certo tempo com a intenção de ser regente, tendo em vista essas coisas que ele viu no primeiro ano. Não me importa o que vai acontecer no meio, porque eu realmente não acho que faça a diferença.

Eu vou exemplificar o que estou dizendo, com uma experiência de um curso de axiomática na graduação em Matemática aqui na UNESP/RC que estou ministrando. Os alunos fizeram Cálculo 1, Cálculo 2, Análise 1, Análise 2, entre outras disciplinas, e quando eu converso com eles sobre coisas do tipo $0,9999 \ldots=1$, parece que eles nunca tiveram um curso. Eu estava conversando com eles no sentido de pensar que objeto é, para a gente, saber o que pode falar sobre ele. Uma aluna me disse que ela tinha estudado em Análise e falava de série e sequência em um pacote só. Para ela a ideia de série estava associada a você ir somando um pouco mais, somando um pouco mais... ou seja, associada a um processo que tem uma questão temporal, uma coisa que a Matemática do matemático expurgou quando passou a operar no plano axiomático. Ela falou para mim que série tem um caráter de processo de aproximação. Ela é uma soma infinita que eu vou somando mais um pouco. Eu disse a ela: infelizmente sou obrigado a dizer, com o coração apertado, que você perdeu uma boa parte dos seus cursos de Análise. Ela riu, seus colegas riram e eu acho que a ficha não caiu, até porque essa é uma coisa dolorosa. Porque estou na frente de alunos do quarto ano e digo para eles: você fez dois ou mais cursos durante um ou mais semestres e você pode jogar fora porque uma série não tem, absolutamente, nada a ver com ir somando mais um termo. Esses caras são alunos do último ano. O que aconteceu com eles no miolo não mudou nada na

${ }^{23}$ Essa dinâmica era feita no Grupo de Pesquisa Ação (GPA), liderado pelos professores Roberto Ribeiro Baldino e Antonio Carlos Carreira de Souza. O Grupo era constituído por diversos profissionais que atuam/atuavam em diferentes áreas da Educação Matemática, Educação Básica e Ensino Superior. A questão básica de pesquisa do grupo é o fracasso do ensino de Matemática e as rotinas que o sustentam.

${ }^{24}$ Seiji Hariki, professor do IME-USP, falecido em 1988. 
percepção matemática deles. Portanto, não pode ter mudado nada no conceito que ela tem sobre o que é uma coisa e o que é outra sobre a Matemática escolar e a Matemática do matemático, porque a Matemática do matemático jamais chegou a ser alguma coisa para ela.

Eu acho que muitos desses alunos estudaram muito e não adiantou muita coisa. Quando eu digo que não adiantou nada eu não estou querendo me referir que para sua formação enquanto professor não serviu nada. Estou querendo me referir a exatamente ao seguinte: para a Matemática do matemático não adiantou nada, ou seja, os professores formadores estão formando pessoas que não têm ideia do que estão falando. O licenciando, depois de cinco anos, não é que ele entendeu de tudo o que se estava falando e chegou à conclusão de que na escola é diferente, e dessa maneira ele vai abandonar o que deram para ele, não é isso. Esse é o cara que fracassou sem ter tido oportunidade de tentar. Esse cara nunca entendeu que o $0,999 \ldots=1$, não se trata de uma concatenação infinita de nós, mas que se trata de um conceito na Matemática do matemático que envolve limite. Esse cara não entendeu isso. A menina disse para mim: 'ah a gente pode pensar em séries e séries a gente vai somando, somando...', ou seja, processo. Não existe na Matemática do matemático processo. O outro menino falava: 'multiplica por 100, a vírgula anda para a direita duas casas'; não existe isso na Matemática do matemático. Mas o cara não abre mão de falar isso depois de quatro, cinco anos de curso de licenciatura. O problema é que ele não consegue entender que ele não pode falar isso lá, mas na escola ele pode, esse é o problema grande. Ele não consegue discernir a questão da legitimidade da produção de significado.

Isso é triste porque, muitas vezes, os alunos se dedicaram para caramba nesses anos acreditando que o que eles estavam aprendendo era importante. O problema é que em grande parte dos cursos de Matemática do matemático, ninguém diz para você que a ideia é outra, ou seja, que certos modos de produção de significados são legítimos. Os professores saem falando e os alunos correm atrás, se cair a ficha, os alunos estão salvos, mas se não cair...

Em relação a essa experiência do miolo, não importa especificamente qual seja, o que importa é que ela seja uma experiência que dê maturidade, autonomia, gosto, quer dizer, que seja uma experiência positiva no sentido muito genérico. O projeto de curso teria uma entrada com as quatro disciplinas (Seminário de Resolução de Problemas, Seminário Light de História da Matemática, Seminário de Educação Matemática) e tem uma saída, que é o professor ministrando aula como regente, que deve ser controlada ao pensar na formação formal.

\section{Parte 2}


, assim engendramos, nesse ensaio, um modo de teorizar em Educação Matemática o que chamamos de movimentos de teorizações. Para construirmos nossas discussões, tomamos a primeira parte deste ensaio como pano de fundo, um chão firme e exemplar. Nossa intenção nesta segunda parte não é explicar o que escrevemos na primeira, nem mesmo relacionar as ideias elaboradas lá de uma maneira mais científica e acadêmica que, de certa forma, poderia nos dar mais legitimidade e até mesmo legalidade para ter elaborado a primeira parte.

Esses escritos se constituem em meio a um desejo político e estético de uma prática de pesquisa em Educação Matemática, resultante de nosso projeto de doutorado (VIOLA DOS SANTOS, 2012). Oferecê-los à comunidade é nosso alvo. Não queremos explicar o que fizemos, nem mesmo justificar nossas escolhas e atitudes frente às demandas e caminhos que atravessamos. Se, em algum momento desta segunda parte isso ficar evidente e até contraditório, por favor, nos perdoem, pois são algumas de nossas pulsões que sobressaem às outras que conseguimos controlar e objetivar. Queremos intensificar uma possibilidade de escrita, uma história a ser elaborada para falar de coisas diferentes das quais falamos, em um movimento que aqui caracterizamos como movimentos de teorizações. O resultado disso, que são vários, todos, cada um, e também nenhum, apresenta algumas ideias de uma estética de pesquisa em Educação Matemática.

Continuaremos nossa empreitada com a discussão de uma Educação Matemática de que falamos; seguimos para outra, que acontece em relação às nossas atitudes teóricometodológicas, o Modelo dos Campos Semânticos (LINS, 1999, 2001, 2012) e a História Oral (GARNICA, 2008; GARNICA, FERNANDES, SILVA, 2011), seguimos mais um pouco e nos desenvolveremos nos movimentos de teorizações...

\section{A Educação Matemática de que falamos}

A Educação Matemática como área de investigação científica se constitui em diferentes, diversos e até mesmos contraditórios processos de teorização. Nos vários cantos do mundo, pesquisadores produzem pesquisas, com variados enfoques teórico-metodológicos, que se relacionam, impactam e transformam, em diferentes graus e medidas, práticas profissionais de professores que ensinam Matemática.

Ao longo do século XX, profissionais da Matemática, Pedagogia, Psicologia, entre outras áreas, dedicaram-se à construção de ideias, princípios e fundamentos para o que hoje chamamos de Educação Matemática. Em encontros, reuniões e congressos discutiam questões didáticas, relacionadas aos processos de ensino e aprendizagem. Aos poucos essas questões se 
ampliaram, abarcando discussões sociais, políticas e culturais. Atualmente, esse campo de investigação se constituiu muito além das fronteiras da disciplina da Matemática, espraiandose por áreas como a Filosofia, Antropologia, História, Linguística...

Ao contarmos uma história da Educação Matemática, lendo o artigo "A educação matemática: breve histórico, ações implementadas e questões sobre sua disciplinarização", publicado por Ubiratan D'Ambrosio e colegas, vemos que

/.../ apenas a partir das três grandes revoluções - a Revolução Industrial (1767), a revolução Americana (1776) e a Revolução Francesa (1789) - que as preocupações com a educação matemática da juventude começam a tomar corpo (p.71, 2004).

Embora desde a antiguidade se tenha registros de preocupações com o ensino de Matemática, D’Ambrosio ainda afirma que,

/.../ o passo mais importante no estabelecimento da educação matemática como uma disciplina é devida à contribuição do eminente matemático alemão Felix Klein (1849-1925), que publicou em 1908, um livro seminal, Matemática Elementar de um Ponto de Vista Avançado (p. 71, 2004).

Segundo D`Ambrosio, a Educação Matemática enquanto área de investigação científica, ainda é muito nova, se compararmos, por exemplo, com a própria Matemática. Nesse sentido, muitas demarcações epistemológicas, políticas e sociais ainda estão em processo de implementação. Estas não são menos que difusas, complexas e resultantes de grandes impasses.

Nesse mesmo artigo citado anteriormente, Antonio Miguel apresenta uma discussão sobre o processo de disciplinarização da prática social em Educação Matemática e inicia sua discussão assinalando que

é uma prática social que não está ainda nem topologicamente diferenciada das demais no interior do espaço acadêmico, nem juridicamente estabelecida como campo profissional autônomo, nem, portanto, institucionalmente reconhecida como campo disciplinar (p. 81, 2004).

Nessa direção, Miguel caracteriza quais seriam os sujeitos que fazem parte da comunidade emergente de Educação Matemática, sendo eles,

professores de matemática que não pesquisam suas práticas e que não veem com bons olhos os pesquisadores acadêmicos em educação matemática; pesquisadores acadêmicos em matemática e em educação que participam da formação desses professores mas que não gostam muito de fazer isso e, se pudessem, não o fariam; de matemáticos que não pesquisam nem matemática e nem educação, mas que formam, a gosto ou contragosto, professores de matemática, mas que se acham impedidos e que desejariam fazer; pedagogos e psicólogos, por alguns considerados matematicamente incultos, mas que realizam pesquisas em educação matemática; matemáticos conteudistas de última hora, moralizadores, arrogantes e inflexíveis, que se imaginam salvadores da pátria e legítimos proprietários e defensores do nível de rigor da educação matemática da população; mas também por professores de matemática, pesquisadores em matemática, pesquisadores em educação matemática e outros profissionais que fazem e acreditam na educação matemática e tentam, de fato, levar a sério o que fazem (p. 89, 2004). 
Seria mesmo ingênuo acreditarmos que essa prática social na qual convivem tantos profissionais de diferentes contextos de atuação, pudesse, em um tão curto espaço de tempo, constituir regulações e princípios norteadores de práticas que nela são mobilizadas. Acreditamos que os terrenos, fronteiras, lugares da Educação Matemática se institucionalizam de maneira complexa e que talvez, não se ajustem aos critérios clássicos das demarcações da ciência ou campo de conhecimento científico. Qual seria o objeto de estudo da Educação Matemática? Seria ela capaz de formular uma teoria? Talvez essas perguntas, mesmo que possíveis de serem feitas, não façam sentido tratando-se da Educação Matemática. Esse é um primeiro aspecto de uma Educação Matemática de que falamos.

Em um número da revista Temas e Debates publicado em 1991 o tema foi: "O que é a Educação Matemática” . Em um artigo dessa revista, João Bosco Pitombeira de Carvalho caracteriza Educação Matemática afirmando que “/.../ ela é o estudo de todos os fatores que influem, direta ou indiretamente, sobre os processos de ensino-aprendizagem em matemática e atuação sobre esses fatores (p. 18, 1991)".

Como o próprio autor assinala, essa é uma definição muito ampla para identificar algumas características da Educação Matemática, mas ele propõe a discussão de alguns fios condutores. Um primeiro seria a preocupação com o ensino-aprendizagem e um segundo seria o reconhecimento da individualidade, do valor e das especificidades da Matemática. Nessa discussão identificamos a Educação Matemática ligada às práticas educativas que envolvem a Matemática e aos fatores que circunscrevem essas práticas.

Outra importante discussão sobre caracterizações para Educação Matemática é o artigo "O desenvolvimento da Educação Matemática como um campo acadêmico" de Jeremy Kilpatrick, apresentado no primeiro centenário da Comissão Internacional sobre Instrução Matemática. Segundo Kilpatrick (2008), a “/.../ educação matemática não é, ela mesma, uma ciência, mas pelo menos algumas de suas pesquisas se encaixam em critérios das ciências sociais” (p. 33-34, nossa tradução). Para Kilpatrick, a Educação Matemática está intimamente relacionada à Matemática, mas há diferenças entre o que é Matemática para o matemático e para o educador matemático. Para o matemático ela é uma ciência que possibilita desenvolver teorias que podem ou não ser aplicadas. Para os educadores matemáticos ela é um meio pelo qual se pode educar os alunos da Educação Básica e do Ensino Superior. Matemática para os matemáticos é singular, enquanto para os educadores matemáticos é plural (KILPATRICK, 2008).

Para exemplificar as relações entre Matemática e Educação Matemática, Kilpatrick afirma que ambas têm “/.../ uma relação sinergética, na qual uma não pode existir sem a 
outra" (p. 36, nossa tradução). Um símbolo que para ele representa essas relações é o do conceito chinês de yin e yang:

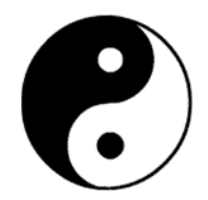

Figura 1 - Símbolo do yin yang Fonte: KILPATRIK (2008)

Em meio a essas discussões, neste ensaio, falamos de uma Educação Matemática como uma atividade de atuação e investigação profissional que permite problematizar certos aspectos (epistemológicos, políticos, sociais, culturais) de certas práticas pedagógicas, investigativas... Geralmente, nessas problematizações, práticas matemáticas estão envolvidas. Entretanto, vale ressaltar que isso não é uma regra e pode acontecer de forma acidental. Em algumas problematizações é necessário focar outros aspectos que não estejam deliberadamente relacionados à Matemática. Em outras, o foco é totalmente relacionado à Matemática, como é o caso, por exemplo, das problematizações que envolvem o ensino e a aprendizagem de algum tópico matemático.

A Educação Matemática é uma atividade que se constitui em diversos e diferentes diálogos com a Filosofia, Antropologia, Sociologia, História, Psicologia, como também com qualquer outra área do conhecimento com a qual educadores matemáticos possam e queiram dialogar. Em meio a isso, o aspecto central do nosso projeto, em relação às nossas práticas de atuação e investigação, é o de educar por meio da Matemática. Que tipos de problemas surgem quando mobilizamos ações para buscar essa meta? Que outros modos legítimos de produzir significados podemos elaborar? O que preciso entender, construir? Contra ou em favor de que se deve lutar para que possamos seguir essa direção e não apenas anunciá-la?

Nesse ensejo, compartilhamos a ideia de se pensar em Educação Matemática ao invés de Ensino de Matemática para educar nossos alunos pela Matemática. Entretanto, qualquer caminho que se desdobre para completar essa frase, como por exemplo, educar nossos alunos pela Matemática para tomar as discussões matemáticas como um meio para construir cidadania e repertórios para que eles possam lidar com o mundo em que vivem, ou mesmo, educar nossos alunos pela Matemática para construir uma postura crítica frente à realidade que eles vivem, ou, para construírem um mundo melhor e promoverem a construção de uma sociedade justa e igualitária, não nos cabe anunciar, pois nossa intenção é construir caminhos constituintes de projetos políticos elaborados com ampla participação dos envolvidos em um contexto específico. Corroboramos os escritos de Lins (2008) quando afirma que 
Na educação matemática que proponho, os conteúdos que vão aparecer na sala de aula só vão ser escolhidos depois que o projeto político for defendido, o que determina os objetivos desta educação. E vão estar presentes como material através do qual se propõe que os alunos tenham oportunidade de se apropriar de certos modos de produção de significados, entendidos como legítimos em relação ao projeto político e a cultura em que se apresenta (p. 547, 2008).

Nos terrenos da Educação Matemática são muitas as posturas teórico-metodológicas utilizadas na produção de conhecimento. Muitas delas já se assentam em princípios e processos de regulações estáveis, outras apenas se anunciam, outras ainda já se encontram superadas. Esboçadas algumas ideias sobre a Educação Matemática que pretendemos defender, vamos, a seguir, apresentar nossas atitudes teórico-metodológicas que sustentam e dão forma ao nosso processo de teorização. Lembramos que nos inscrevemos em um processo de possibilidades de intensidades, em um movimento de alinhavar uma prática de teorizar.

\title{
2 Modelo dos Campos Semânticos
}

O Modelo dos Campos Semânticos (MCS) foi (e continua sendo) elaborado pelo professor e pesquisador Romulo Campos Lins, a partir de seu estudo de doutorado (LINS, 1992), em relação aos modos de produção de significados de alunos da Educação Básica para a álgebra escolar. Ao longo desses anos, as noções dessa teoria vêm sendo ampliadas, sistematizadas e utilizadas por diversos pesquisadores em várias pesquisas em Educação Matemática $^{25}$.

O aspecto central do MCS, do qual todas outras noções derivam, é a caracterização de conhecimento. Lins (2001) apresenta três aspectos chave para sua caracterização de conhecimento,

\begin{abstract}
/.../ primeiro, é que a pessoa deve acreditar em algo que constitui parte do conhecimento que produz, o que implica estar consciente dessa crença; segundo, a única maneira que podemos estar seguros e conscientes é se a pessoa declara (e aqui utilizo declara de maneira livre) significado em alguma forma de comunicação aceita por um interlocutor ${ }^{26}$; e, terceiro, não é suficiente considerar o que a pessoa acredita e declara, pois diferentes justificações para uma mesma crença-afirmação corresponde a diferentes conhecimentos (p. 42, nossa tradução).
\end{abstract}

Em meio a isso, o conhecimento, segundo o MCS, é "uma crença afirmação junto com uma justificação que me autoriza a produzir aquela enunciação (Lins, 1999, p 88)”. Não é uma justificativa que dá sentido ou mesmo justifica a crença afirmação, como também não é uma justificativa que tem o papel de explicitar a crença afirmação, pensando de maneira

\footnotetext{
${ }^{25}$ Silva (2003); Linardi (2006); Oliveira (2002, 2011); Julio (2008); Silva (2006), para citar algumas.

${ }^{26}$ Segundo o MCS, o interlocutor é a direção para qual eu me coloco a falar. Discutiremos com mais detalhes essa noção no decorrer deste ensaio.
} 
separada da crença afirmação. A justificação é constituinte do conhecimento. Segundo Lins (2001), elas [as justificações]

\begin{abstract}
têm um duplo papel em relação ao conhecimento. Primeiro, elas estão relacionadas a conceder o direito de conhecer, e esta concessão é sempre feita na direção de um interlocutor para quem o conhecimento está sendo enunciado. Segundo, elas estão relacionadas à constituição de objetos (p. 42, nossa tradução).
\end{abstract}

Ao conhecer, constituímos ações enunciativas em uma direção que acreditamos que o outro nos legitimaria, produzindo significados por acreditarmos que pertencemos a algum espaço comunicativo $^{27}$. A justificação é a legitimidade de nossa enunciação e o que nos autoriza a produzir significados. Como afirmam Lins e Gimenez,

Todo conhecimento é produzido na direção do outro, o que quer dizer que o sujeito que o produz deve acreditar que alguém compartilha com ele aquela justificação (1997, p. 142).

Em princípio, alguém pode considerar que essa caracterização de conhecimento estabelece um relativismo total, um vale tudo, no qual tudo pode ser caracterizado como conhecimento, pois se conhecimento é uma crença-afirmação junto com uma justificação, podemos nos colocar a construir crenças-afirmações com justificações. Entretanto, Lins e Gimenez (1997) afirmam que essa ideia não é válida e apresentam dois argumentos para isso:

Primeiro, porque não é tudo que pode ser dito, já que qualquer dada cultura aceita alguns, mas nunca todos os modos possíveis de produzir significados. [Segundo] o próprio processo de produzir significados estabelece limites "internos" (p. 143).

Os exemplos são vários e apresentamos dois que acreditamos exemplificar esses argumentos. Se declararmos que voaremos pelo céu de uma cidade porque transformamos nossos esqueletos, por meio de contatos com extraterrestres, em uma máquina mecânica voadora, acreditamos que grande parte das pessoas com as quais convivemos não produziriam significado legitimando essa direção de interlocução. Eles até entenderiam essas frases. Talvez até imaginariam nossos voos. Porém, não acreditariam que isso pudesse ocorrer. Essa crença-afirmação junto com essa justificação não é aceita, pelo menos em relação aos leitores com os quais compartilhamos um espaço comunicativo. Se ficarmos repetindo isso para nossos leitores, eles chegariam à conclusão que estamos loucos o que, segundo o MCS, nada mais é do que a pessoa que produz significados legítimos para alguns leitores, mas que muitos outros, ou a grande maioria, não legitimam. Esse seria um exemplo que mostra que não é qualquer modo de produzir significado que é aceito em uma determinada cultura. Um segundo exemplo seria em relação aos limites de produzir significados no interior de uma atividade. Lins e Gimenez (1997) afirmam que não é possível resolver a equação 3x $+100=$

27 Segundo o MCS um espaço comunicativo é um processo de interação no qual interlocutores são compartilhados (LINS, 2012, p. 24). 
10, por meio da produção de significados da metáfora da balança de dois pratos. Como é possível, pensando a equação como uma balança, retirar 100 quilos de cada membro da equação, se no segundo membro temos apenas 10 quilos? Esses são dois exemplos que mostram que essa caracterização de conhecimento não cai no relativismo total.

Essa caracterização apresenta possibilidades para superar algumas ideias que ainda se apresentam enraizadas, percebidas em pequenas deixas, nas falas de muitos educadores matemáticos (por mais que muitos afirmem que elas já estão superadas). Uma primeira é um objetivismo, pensado aqui como a ideia de que existe de fato a verdade e que queremos alcançá-la. Se eu utilizar essas estratégias no momento certo e da maneira correta, tenho certeza que ensinarei a meus alunos equação do primeiro grau. Uma segunda seria a de um absolutismo, pensado aqui como a ideia de que existe UM único significado para A Matemática. Função é uma relação entre dois conjuntos... Eu tenho sempre que começar pelas definições e os alunos precisam aprendê-las. Uma terceira ideia é que essa caracterização apresenta possibilidades de olharmos para o outro e não caracterizá-lo pela falta. Você não sabe isso; você não fez aquilo; infelizmente não posso considerar suas ideias, pois nelas faltam muitas considerações; esse aluno errou essa questão, pois faltou ele entender essa segunda frase no problema, os exemplos são muitos...

Outra problemática superada por essa caracterização de conhecimento é a de que "não se pode conhecer o que não é verdadeiro (LINS, 1999, p. 89)". A caracterização de conhecimento, por meio do MCS, coloca essa questão sob outro ponto de vista que nos possibilita sair de questionamentos sobre o que é verdadeiro ou como se pode dizer que algo é, ou não, verdadeiro. Segundo Lins “a própria enunciação que faz [o conhecimento] existir garante que ele é verdadeiro para alguém [esse alguém tomado como ser cognitivo]" (p. 89).

Aventuramo-nos por essas considerações, destacamos a noção de legitimidade na/de justificação, um dos focos centrais deste ensaio. Um ponto chave, e já alinhavado nos parágrafos anteriores, é de que produzimos conhecimento na direção de um interlocutor, o qual, acreditamos, legitimaria as coisas que dizemos. A legitimidade de nossa crençaafirmação não é estabelecida por uma verdade (pelo que pode ou não ser dito), nem mesmo por critérios lógicos deduzidos axiomaticamente, nem por empíricos observados em determinadas situações. Essa legitimidade é estabelecida por acreditar que pertencemos a algum espaço comunicativo (LINS, 1999). Colocarmo-nos em movimentos de produção de legitimidades é constituir crenças-afirmações junto com justificações na direção de interlocutores que acreditamos autorizariam (legitimariam) essas produções; é compartilhar 
interlocutores e construir um espaço comunicativo no qual seria possível produzir outros modos legítimos de produção de significados para a formação matemática de professores.

Abordando a problemática de que diferentes justificações para uma mesma crençaafirmação estabelecem diferentes conhecimentos, apresentamos um exemplo do trabalho de mestrado de Viviane Oliveira.

Consideramos que tanto um aluno por volta dos quatorze anos quanto um
matemático, acreditam e afirmam que $2 \times(-3)=(-3) \times 2$. Ao justificar sua crença
afirmação o aluno poderia dizer 'Se fizermos as contas, vamos ver que $2 \times(-3)$ é
igual a (-6) e que $(-3)$ x 2 é igual a $(-6)$; tanto $2 \times(-3)$ como $(-3) \times 2$ são igual a $(-6)$.
Por isso é que eu digo que $2 \times(-3)=(-3) \times 2$.' Já o matemático, talvez dissesse
'Sabemos que 2 e $(-3)$ são números inteiros. Como para o conjunto dos números
inteiros, munidos das operações usuais da adição e da multiplicação, vale a
propriedade comutativa da multiplicação, digo que $2 \times(-3)=(-3) \times 2$ ' (OLIVEIRA,
p. 24,2002$)$.

A crença afirmação, tanto do matemático quanto do aluno, é a mesma. Entretanto, a justificação do aluno e do matemático são diferentes. Assim, os conhecimentos produzidos pelo aluno e pelo matemático são diferentes. Como explicitado anteriormente, conhecimento é uma crença-afirmação e uma justificação, as duas ideias juntas e constitutivas da caracterização de conhecimento. Lins (1999) destaca que o conhecimento não se encontra nos livros, sítios da internet, ou qualquer outra mídia e afirma que

/.../ dado que conhecimento é do domínio da enunciação, esclarece-se suficientemente que não há conhecimento em livros enquanto objetos, pois ali há apenas enunciados. É preciso a enunciação efetiva daqueles enunciados para que eles tomem parte na produção de conhecimentos. (p. 89).

Utilizamos muitas noções sem tê-las definido com detalhes. Começamos essa empreitada por significado, outra noção do MCS. Significado é aquilo que o sujeito pode e efetivamente diz sobre um objeto no interior de uma atividade (LINS, 1999, 2001). Silva (2003) exemplifica

/.../ "poder dizer”, presente na formulação de significado, está intimamente relacionado à questão da legitimidade. Como consequência, dizer que o sujeito produziu significado é dizer que ele produziu ações enunciativas a respeito de um objeto no interior de uma atividade (p.21)

A produção de significado não se restringe apenas à fala, também engloba a escrita, os gestos. Um ponto importante a ser destacado é que o significado de algo não é produzido em relação ao que alguém poderia dizer em algum contexto ou mesmo em relação ao que alguém não disse. $\mathrm{O}$ sujeito produz significados em relação a algo que ele pode e efetivamente diz no interior de uma atividade.

Para esse algo que o sujeito produz significado, Lins elabora a ideia de objeto. Assim, objeto é "algo a respeito de que se pode dizer algo" (2004, p. 114). Dessa maneira, à medida que produzimos significados, constituímos objetos. Os alunos produzem significados e 
constituem objetos quando lidam com um problema. Quando nos deparamos com um livro produzimos significado e constituímos objetos. Vale lembrar que a produção de significados e a constituição de objetos não se dão de maneira separada. Muito pelo contrário, pois os objetos são constituídos à medida que produzo significados para eles. Segundo Lins,

/.../ eu me constituo enquanto ser cognitivo através da produção de significados que realizo, ao mesmo tempo em que constituo objetos através destas enunciações, ou seja, é na produção de significados que se constituem objetos $(1999$, p. 86).

Um sujeito produz significados e constitui objetos em uma direção que acredita ser legítima. Essa direção à qual nos colocamos a falar é chamada por Lins de interlocutor. Segundo o autor,

/.../ ao produzir significado, minha enunciação é feita na direção de um interlocutor que, acredito, diria o que estou dizendo com a justificação que estou produzindo. /.../ Toda produção de conhecimento é feita na direção de um interlocutor que, acredito, produziria a mesma enunciação com a mesma justificação $(1999$, p. 88).

Esse interlocutor não corresponde a um ser biológico, mas sim a um ser cognitivo. Quando produzimos significados constituindo objetos em uma direção, acreditamos que esses significados são legítimos, ou seja, que podem ser enunciados no interior de uma atividade e que nossos interlocutores os aceitariam e legitimariam. Por exemplo, ao escrever essas palavras que formam frases e constroem parágrafos, acreditamos que nossos interlocutores (um tal José, mestrando em Educação Matemática que estuda formação matemática de professores, ou um tal Antônio, doutorando em Educação, que estuda dinâmicas de sala de aula, um tal Pedro que..., um tal...) aceitariam como legítimos, os significados que produzimos e os objetos que constituímos ${ }^{28}$. Quando falamos em uma direção acreditamos que pertencemos a um espaço comunicativo, ou seja, a uma atividade em que existe "compartilhamento de interlocutores (LINS, p.88)".

Essas ideias estão relacionadas a uma perspectiva de oferecer uma possibilidade de ler a atividade de alguém ou de lidar com algo. Não se busca uma permanência, uma essência, ou algo que foi dito por aquele sujeito. Busca-se uma possibilidade de interação e a constituição de espaços comunicativos.

Quando lemos um livro, produzimos significados e constituímos objetos naquele momento, naquela situação. Lemos acreditando que aquilo que “estamos entendendo” seria o que o autor diria, colocamo-nos a compartilhar interlocutores que acreditamos que o autor compartilharia. Entretanto, podemos pensar em direções totalmente diferentes daquela que o

\footnotetext{
${ }^{28}$ Acreditamos que aqui a ideia de interlocutor como ser cognitivo e não como um ser biológico fica explícito, pois José, Antônio, Pedro existem para nós apenas como ideias de possíveis sujeitos que um dia poderão ler esse ensaio. Não escrevemos em relação ao Pedro, ao José, ao Antonio (seres biológicos), mas em relação a um José, a um Pedro, a um Antonio (seres cognitivos).
} 
autor pensou e isso, sendo essas também legítimas. Pontuando nossa fala, o autor do livro que leio somos nós. De fato, somos autores de todos os livros que já lemos e de todos aqueles que ainda leremos. Mesmo que esteja escrito na capa o nome do autor, a data de publicação do livro, os dizeres sobre direitos autorais que ele tem sobre sua obra; quando lemos o livro, produzimos significados e constituímos objetos, nos constituindo como autor naquela atividade.

Assim, os livros, as definições matemáticas, as obras de arte, os sons das músicas que tocam no rádio, as propagandas nas fachadas dos prédios, são todos textos que, segundo Lins (1999), “/../ são resíduos de enunciações para os quais eu produzo significado” (p. 88)”. Apenas existe texto quando temos autor. Não faz sentido, dentro do MCS, pensar em um texto sem pensar em um autor que lê o texto.

Nesse nosso esforço de registrar linearmente algumas noções centrais do MCS, acreditamos ter alinhavado algumas de nossas atitudes teórico-metodológicas. Falar em conhecimento implica falar em interlocutor, o que implica falar de produção de significado, e assim por diante ${ }^{29}$. Passamos agora a outras crenças-afirmações junto a justificações que regulam e constituem a produção desse ensaio e delimitam fronteiras imagináveis de nossos movimentos de teorizações.

\section{História Oral}

Ao lado (ou em cima, embaixo, no meio, misturado) do Modelo dos Campos Semânticos, outra atitude teórico-metodológica deste trabalho é a História Oral. Dentre os diversos vieses de se caracterizar História Oral, praticamos um modo particular que se fundamenta em trabalhos do Grupo de História Oral e Educação Matemática (GHOEM) ${ }^{30}$. Apresentamos algumas características que nos interessam nesse trabalho ${ }^{31}$.

\footnotetext{
${ }^{29}$ Vale ressaltar que várias outras noções do MCS não foram discutidas neste ensaio. Para mais informações consultar LINS (1999, 2001, 2012) e acessar o site www.sigma-t.org

${ }^{30}$ Para mais informações sobre o GHOEM acesse o site www.ghoem.com.

${ }^{31}$ Não é de nosso interesse, neste ensaio, tecer considerações sobre pressupostos de como entender história ou mesmo praticar uma historiografia. Entretanto, apresentamos algumas ideias sobre práticas historiográficas do GHOEM que compartilhamos para dar uma direção, mesmo que primeira (inicial). Uma maneira de se pensar a história, é a ideia de que precisamos estudar o passado para entender o presente e prever o futuro. Este modo de pensar a história como progresso não é a perspectiva adotada. A ideia adotada é a de que, a partir do presente, construo histórias. Significamos, elaboramos, presentificamos um passado, em meio a subjetividades e parcialidades naturais desse processo. Um passado, pois em um futuro pode-se construir outros. Não reconstruímos, não resgatamos, nem mesmo nos colocamos a construir a história tendo como objetivo dizer como ela aconteceu. Segundo Garnica, Fernandes, Silva (2011) “cabe ao historiador presentificar ausências, trazendo para uma discussão do presente, no presente e sobre o presente, toda uma sorte de descortinamentos criados a partir do diálogo com o passado. O passado é a ausência, o passado é a inexistência que nos
} 
Pode parecer um pouco estranho um trabalho que não tem por objetivo estudar algum tema relacionado à História da Educação Matemática tomar como fundamentação a História Oral. Essa é, ainda, uma sensação recorrente de muitos que se limitam a pensar que para utilizar a metodologia de história oral é necessariamente necessário fazer pesquisa em história. Outro aspecto que também pode levar a essa sensação é que grande parte dos trabalhos do GHOEM, que utilizam História Oral como metodologia, tem por objetivos estudar aspectos da História da Educação Matemática ${ }^{32}$. Entretanto, essa é apenas uma sensação, uma estranheza que se desmistifica ao se estudar características dessa atitude teórico-metodológica de pesquisa qualitativa.

A História Oral como método de pesquisa qualitativa em Educação Matemática se configura como uma possibilidade para realizar trabalhos que envolvem, intencionalmente, a produção de fontes por meio de entrevistas. Segundo Garnica (2010)

\section{/.../ um trabalho - em Educação Matemática ou em qualquer área que seja - produz irremediavelmente uma fonte histórica. A diferença é que os que usam a História Oral intencionalmente as produzem (p. 31).}

Assim, podemos, por exemplo, produzir fontes históricas e investigar aspectos da formação matemática de professores de Matemática, sem realizar um trabalho na área de História da Educação Matemática. Ainda segundo Garnica,

/.../ a História Oral em Educação Matemática é um “método-em-trajetória" de natureza qualitativa, o qual pressupõe que um método configura-se dinamicamente, de forma processual, e não pode ser estabelecido aprioristicamente, sem que haja um objeto específico para ser investigado, uma vez que nas pesquisas de natureza qualitativa são os objetos que exigem procedimentos específicos para compreendê$\operatorname{los}$ (p. 32, 2010).

A História Oral é um método de pesquisa qualitativa em Educação Matemática, e não (apenas) um método de pesquisa qualitativa em Educação Matemática para realizar pesquisa em História da Educação Matemática. É um método sobre o qual cada trabalho realizado exercita possibilidades e regulações, testa seus limites e possibilita outros caminhos para investigar aspectos da complexidade das instâncias da Educação Matemática. Como Garnica (2010) afirma, "cada pesquisa realizada no GHOEM serve - serviu e continua servindo - para uma análise metodológica que dá parâmetros para avaliar os sucessos e as limitações do método" (p. 32).

assombra, o passado é uma criação do presente, ou de outro modo, o passado é o que dele se diz no presente. O passado é uma composição à qual, no presente, eu procuro atribuir significados para o presente". Essas são algumas características que circunscrevem as práticas de pesquisa do GHOEM.

${ }^{32}$ Vale ressaltar que existem trabalhos que não têm essa intenção e que utilizam a história oral como metodologia de pesquisa, como os de Souza (2006), Rolkouski (2006), Garnica (2008). 
Um fator significativo dessa metodologia são as textualizações. Os pesquisadores, por meio de entrevistas gravadas e/ou filmadas, elaboram textualizações que são apresentadas integralmente no corpo dos trabalhos. Entretanto, essas textualizações não se constituem em uma apresentação dos dados para que depois o pesquisador teça suas análises, ou como um exercício analítico em si: são narrativas apresentadas frente à intenção de permitir acesso aos leitores e pesquisadores que possam tomá-las para outras pesquisas. As textualizações constituem-se como movimentos de análises, teorizações, construção de narrativas que permitem compreensões do tema pesquisado. Elas se constituem dessa maneira, pois a ação de textualizar carrega em si vieses teóricos do pesquisador que se manifestam na escolha dos depoentes, na elaboração dos roteiros das entrevistas, nas dinâmicas segundo as quais elas são realizadas. A postura qualitativa do pesquisador nesse processo se inscreve em seus desejos, crenças, concepções, subjetividades, ou seja, em um todo político cultural que circunscreve sua prática de pesquisa, que se constitui em produzir narrativas a partir de momentos de entrevistas, e também outras narrativas de análises, teorizações, alinhavos, sistematizações, num processo inesgotável de produção de narrativas.

Textualizar se aproxima do movimento de escrever o que acredito que alguém escreveria, constituindo um texto que acredito que alguém diria que é seu. Assim, não buscamos apenas tirar os vícios de linguagem, reescrever as frases truncadas (que no momento de entrevista são naturais), reorganizar o texto de uma maneira que ele fique mais corrente, "palpável” para leituras. Colocamo-nos a escrever outro texto que é constituído a partir da gravação (áudio ou áudio-visual) e armazenamento em mídia, da entrevista realizada, como também de nossas lembranças daquele momento. Não escrevemos as mesmas coisas que o depoente disse, mesmo se utilizarmos as mesmas palavras. Colocamo-nos em um movimento de instituir palavras, plausivelmente, de uma maneira que acreditamos que o entrevistado diria.

Não há pretensão de escrever o que de fato o depoente falou. Para nós está claro que o que ele disse morreu, não existe mais. O que temos é apenas uma mídia que reproduz, por meio de um aparelho, falas de duas pessoas; uma que reconhecemos como sendo nossa e outra, a dele. Acreditamos que quando escutamos essa gravação, temos algumas direções de como construir um texto de uma conversa (entrevista).

Como já não temos a esperança de escrever o que conversamos, nos colocamos em um movimento de produzir significados e constituir objetos que, acreditamos, o depoente legitimaria. Inserimo-nos em um movimento de textualizar, produzir narrativas em um 
esforço conjunto entre pesquisador e entrevistado, cada um operando a cada momento. Como afirma Silva (2006),

/.../ praticar a textualização em história oral é um exercício de amalgamar a ficção que o outro é à ficção que somos nós, ou seja, é uma tentativa de nós, pesquisadores, nos aproximarmos dos significados que o depoente produz para as suas experiências (p.423-424).

Nos terrenos da História Oral, o ingrediente fundamental são as narrativas. Souza, Guedes e Silva (2011) discutem os usos e possibilidades de análises de narrativas. Os autores abordam o tema mostrando como a narrativa era utilizada em rituais de tribos e etnias, e como esse modo de produzir conhecimento foi deixado de lado na modernidade, que buscou uma institucionalização do conhecimento histórico. Silva (2006) citando Lyotard (1986) afirma que

/.../ diferentemente do discurso científico caracterizado por enunciados denotativos, o discurso narrativo admite uma pluralidade de jogos de linguagem (enunciados denotativos, deônticos, interrogativos, avaliativos, etc.), cujas competências encontram-se misturadas umas às outras num tecido cerrado, o do relato, e ordenadas numa perspectiva de conjunto, que caracteriza este gênero de saber (pp. $409,410)$.

Bolívar (2002) também contribui nessa direção afirmando que

El ideal positivista fue establecer una distancia entre investigador y objeto investigado, correlacionando mayor despersonalización con incremento de objetividad. La investigación narrativa viene justo a negar dicho supuesto, pues los informantes hablan de ellos mismos, sin silenciar su subjetividad (p. 2).

Partindo do pressuposto de que não existe uma verdade lógica, imutável, intrínseca a um objeto e que são nas circunstâncias da linguagem, nas relações culturais, políticas, sociais que os significados são produzidos e são constituídos objetos na direção de um interlocutor que legitimaria esses modos de produção, as narrativas, constituídas em experiências idiossincráticas, num determinado momento e contexto cultural, permitem olhares singulares sobre a complexidade de um tema. Não narramos apenas os fatos que vivemos, nem mesmo relatamos apenas nossas opiniões sobre algo. Quando narramos nos constituímos. Narrar é constituir-se nas possibilidades e conflitos de um possível experienciar, nos labirintos da linguagem, nos posicionamentos frente aos desejos do outro.

Assim, as narrativas construídas a partir de momentos de entrevistas não se constituem presas a certas categorizações, tabelas, ou recortes que o pesquisador possa fazer. Elas são integrais em seus detalhes e particularidades, idiossincráticas no corpo do texto e se apresentam em direções para que outras narrativas possam ser elaboradas. Souza, Cury e Silva (2011) apresentam uma direção legítima para essa argumentação, afirmando que 
Sobre o modo narrativo, Bruner (1997) afirma que este parte do princípio de que as ações humanas são únicas e irrepetíveis. Sua riqueza de matizes não pode, então, ser exibida em direções, categorias ou proposições abertas (p. 7).

Ainda sobre narrativa, Garnica (2011) assinala que ela

\begin{abstract}
expressa o que é possível dizer, num mundo onde esses ditos ressoam. As narrativas, registros da ação, permitem compreender algumas das crenças segundo as quais as pessoas agem. Permitem compreender que não há manutenção eterna nem alteração frequente: mostram que mantemos hábitos no esforço de rompê-los, que afirmamos querer romper hábitos para que possamos mantê-los. Ao fim e ao cabo, mostram que vivemos num mundo no qual esses discursos têm lugar e, de um modo ou outro, fazem sentido (p. 7).
\end{abstract}

A produção de conhecimento por meio de narrativas apresenta-se como uma possibilidade dada a complexidade do mundo em que vivemos. Os homens alinhavam alguns aspectos no momento em que eles se constituem por meio de narrativas. Ao se constituírem, instauram lugares, ideias, direções. Caracterizamos narrativas, seguindo a direção de Bolívar (2002)

la cualidad estructurada de la experiencia entendida y vista como un relato; por otro (como enfoque de investigación), las pautas y formas de construir sentido, a partir de acciones temporales personales, por medio de la descripción y análisis de los datos biográficos (p.5).

Posto essas ideias em relação a essa segunda atitude teórico-metodológica, seguimos para nosso foco central deste ensaio.

\title{
4 Movimentos de Teorizações
}

Em nossa tese de doutorado (VIOLA DOS SANTOS, 2012), produzimos possíveis legitimidades para a formação matemática de professores de Matemática em cursos de Licenciatura em Matemática. Tais legitimidades foram construídas por meio de movimentos de teorizações a partir de textualizações de entrevistas realizadas com matemáticos e educadores matemáticos e de textos teórico-analíticos elaborados ao longo dos quatro anos de realização de nosso projeto.

Nesse processo de construção, não argumentamos na direção dos verdadeiros argumentos que devem ser os balizadores da estrutura dos cursos de Licenciatura em Matemática, nem mesmo os únicos para se pensar uma formação matemática na Licenciatura. As legitimidades, ou seja, os modos legítimos de produzir significado, que elaboramos em torno da formação matemática de professores, foram apenas alguns, como poderiam ser outros. 
Não analisamos, no sentido de apresentar um conjunto de categorias construídas em um processo recursivo a partir de unidades, o que educadores matemáticos e matemáticos dizem a respeito da formação matemática. Produzimos alguns textos que, por sua vez produzem possíveis legitimidades. Falamos em direções que pareciam ser plausíveis para produzir tais discursos sobre a formação matemática de professores de Matemática. Essa produção se fez a partir de alguns movimentos de teorizações que constituem o trabalho.

Cada textualização construída com nossos depoentes, cada texto teórico-analítico, aqui entendido como um texto que se constitui em meio a estudos analíticos nas/pelas/sobre/com as textualizações como também em conjunto aos estudos teóricos elaborados pela comunidade de pesquisadores em Educação Matemática, todas as circunstâncias, encontros e desencontros, constituem um e se constituem num movimento de teorização a respeito da formação matemática de professores de Matemática. A primeira parte deste ensaio é um exemplo exemplar da textualização como possibilidade de produção de conhecimento, construída por meio de uma entrevista realizada pelo primeiro autor do artigo com o segundo.

Nossa ideia foi a de que cada texto se constituiria como uma possível legitimidade para a formação matemática de professores de Matemática e que o processo de teorização ocorreria em todos. Não nos colocamos a esboçar ideias teóricas para, a partir delas, investigar o que meus depoentes falaram. Não nos colocamos a descrever os dados para depois analisá-los em um processo recursivo para construir categorias e, a partir delas, escrever as considerações finais de nosso trabalho.

Em relação às textualizações, o processo de teorização ocorreu desde quando elaboramos o roteiro, ao realizarmos as entrevistas, ao textualizá-las e enviá-las aos nossos depoentes para que pudéssemos juntos, escrever um texto no qual eles acreditavam que exprimiam suas opiniões.

Os textos teórico-analíticos foram construídos a partir de estudos, discussões, leituras das textualizações, das conversas que tínhamos, nossas reflexões, ou seja, a partir de todas as circunstâncias que circunscreveram a produção de nossa tese de doutorado. Acreditamos que não temos possibilidade, como também para nós não faz sentido, delimitar quando as ideias dos textos teórico-analíticos surgiram.

Nossa intenção não foi a de utilizar um processo recursivo para a construção de grupos ou categorias para aflorar e construir argumentos a respeito da formação matemática de professores. Nosso trabalho foi produzir possíveis legitimidades das quais emergiram, em direções e falas, crenças e ideias a respeito do tema, criando, a partir disso, movimentos de teorizações. 
Produzimos dezoito narrativas que são independentes e falam de questões particulares a respeito da formação matemática. Na tese, não há intenção de um se constituir como mais ou menos importante que o outro, nem de apresentar o que acreditamos ser o que e como deve ser a formação matemática nas Licenciaturas.

Os movimentos de teorizações se caracterizam por processos nos quais produzimos conhecimento por meio de um relato sistematizado de experiências. Ao teorizarmos, contamos uma história, produzimos significado e constituímos objetos em uma direção. Nesse movimento, abrimos mão do que é particular com intenção de constituir algo diferente do que falamos, do que já foi dito. Esse movimento é mais que descrever: ele se constitui como um contar, narrar uma história para que podemos repetir, refletir e, quiçá, apresentar uma síntese, alguma sistematização, mesmo não tendo essa intenção. Ao teorizarmos, produzimos possíveis legitimidades em espaços, traços, textos, rascunhos, vivências, circunstâncias, subversões... Nossa experiência institui palavras e, nos movimentos de teorizações, ocupamos espaços transitórios nos labirintos da subjetividade. Larrosa (2006) explicita uma ideia nessa direção ao afirmar que os textos estão "distanciados de qualquer pretensão de objetividade, de universalidade ou de sistematicidade, e inclusive de qualquer pretensão de verdade, [mas] nem por isso renunciam a produzir efeitos de sentido" (p. 7).

\section{Para um último alinhavo}

Se alguém nos perguntasse como se caracterizaria nosso processo de teorização que anunciamos no início desse ensaio, responderíamos que ele se constitui em cada palavra, frase e parágrafo desses escritos. Não queremos enquadrá-lo em uma definição estática e pontual. Não engendramos todas essas ideias e tessituras, por meio de nossas vicissitudes idiossincráticas, para chegar a uma espécie de considerações finais.

Como escrevemos no último parágrafo de nossa tese, "Em relação "À LEGITIMIDADE" para a formação matemática de professores de Matemática, fico com dois pontos:", fazemos aqui da mesma maneira, também começando com uma vírgula, mas agora terminando com "três pontinhos".

Nosso processo de descrever um modo de teorizar em Educação Matemática se constitui como outro processo de teorizar, de elaboração de intensidades e subjetividades, de modos de produção de significados, de movimentos de teorizações.

Uma estética de pesquisa em Educação Matemática acontece acontecendo, ao nos colocarmos, de maneira quase que esquizofrênica, a olhar para nós mesmos e lermos nosso 
caminhar nos labirintos de nossa linguagem, ao parar em uma vírgula, em três pontinhos e nunca em um ponto final.

Ao falar de um processo de teorização em Educação Matemática, teorizamos e...

\section{Referências}

BOLIVAR, A. “De nobis ipsis silemus?”: Epistemología de la investigación biográficonarrativa en educación. Revista Electrónica de Investigación Educativa, Barcelona, v. 4, n. 1, p. 2-26, 2002. Disponível em: < http://redie.uabc.mx/vol4no1/contenido-bolivar.html>. Acesso em: 18 jun. 2014.

CARVALHO, J. B. P. F. O que é educação matemática. Temas e Debates, Rio Claro, v. 4, n. 3, p. 17 26, 1991.

GARNICA, A. V. M. Revisitando Atalhos: algumas considerações sobre a Licenciatura em Matemática. In: ENCONTRO REGIONAL DE EDUCAÇÃO MATEMÁTICA DE IJUÍ, 2., 2001, Ijuí. Anais... Ijuí: Editora da Unijuí, 2001. p.18-32. CD-ROM.

GARNICA, A. V. M. História Oral e Educação Matemática. In: BORBA, M. C.; ARAUJO, J. L. (Org.). Pesquisa Qualitativa em Educação Matemática. Belo Horizonte: Autêntica, 2004. [77-98]

GARNICA, A. V. M. A experiência do labirinto: metodologia, história oral e Educação Matemática. São Paulo: Editora Unesp, 2008.

GARNICA, A. V. M.; FERNANDES, D. N.; SILVA, H. Entre a amnésia e a vontade de nada esquecer: notas sobre Regimes de Historicidade e História Oral. Bolema, Rio Claro, v. 25, n. 41, p. 213-250, 2011.

JULIO, R. Uma leitura da produção de significados matemáticos e não-matemáticos para dimensão, 2007, 118p. Dissertação (Mestrado em Educação Matemática) - Instituto de Geociências e Ciências Exatas, Universidade Estadual Paulista, Rio Claro, 2007

KILPATRIK, J. The development of mathematics education as a academic field. In: The First Century of the International Commission on Mathematical Instruction. MENGHINI, M.; FURINGHETTI, F.; GIACARDI, L.; ARZARELLO, F. (Ed.). Roma: Instituto Della. 2008. p. 25-39.

LARROSA, B. J. Notas sobre a experiência e o saber da experiência. Revista Brasileira de Educação, Rio de Janeiro, n.19, p. 20-28, 2002.

LARROSA, B. J. Pedagogia Profana. Belo Horizonte: Autentica, 2006

LINARDI, P. R. Rastros da formação Matemática na prática profissional do professor de matemática. 2006. Tese (Doutorado em Educação Matemática) - Instituto de Geociências e Ciências Exatas, Universidade Estadual Paulista, Rio Claro, 2006.

LINS, R. C. A framework for understanding what algebraic thinking is. 1992. 120. Thesis. (PhD in Mathematics Education). Centre for Research in Mathematics Education. University of Nottingham, Nottingham , 1992

LINS, R. C.; GIMENEZ, J. Perspectivas em aritmética e álgebra para o século XXI. Campinas: Papirus, 1997. 
LINS, R. C. Por que discutir Teoria do Conhecimento é relevante para a Educação Matemática. In: BICUDO, M. A. V. (Org.). Pesquisa em Educação Matemática: Concepções e Perspectivas. Rio Claro: Editora Unesp, 1999. p. 75-94.

LINS, R. C. The production of meaning for Algebra: a perspective based on a Theoretical Model of Semantic Fields. In: SUTHERLAND, R.; ROJANO, T.; BELL, A; LINS, R. Perspectives on School Algebra. Netherlands: Kluwer Academic Publishers, 2001. p. 37-60.

LINS, R. C. Characterizing the mathematics of the mathematics teacher from the point of view of meaning production. In: INTERNATIONAL CONGRESS ON MATHEMATICAL EDUCATION, $10^{\text {th }} ., 2004$, Copenhagen. Proceedings... Copenhagen: Plenary and Regular Lectures, 2006, p. 1-16.

LINS, R. C. Matemática, monstros, significados e educação matemática. In: BICUDO, M. A. V.; BORBA, M. C. (Org.). Educação Matemática: pesquisa em movimento. São Paulo: Cortez, 2004, p. 92-120.

LINS, R. C. Design e Implementação de um programa de formação continuada de professores de Matemática. Projeto de pesquisa apresentado ao CNPq para obtenção de bolsa-produtividade. 2006.

LINS, R. C. A diferença como oportunidade para aprender. In: PERES, E.; TRAVERSINI, C.; EGGERT, E.; BONINI, I. (Org.). Processos de ensinar e aprender: sujeitos, currículos e cultura: livro 3. Porto Alegre: Edipucrs, 2008, p. 530-550.

LINS, R. C. O Modelo dos Campos Semânticos: estabelecimentos e notas de teorizações. In: ANGELO, C. L. BARBOSA, E. P.; VIOLA DOS SANTOS, J.R.; DANTAS, S.C.; OLIVEIRA, V.C.A. Modelo dos Campos Semânticos e Educação Matemática: 20 anos de história. São Paulo: Midiograf, 2012, v. 1, p. 10-20.

LISPECTOR, C. A Paixão segundo G.H. Editora: Rio de Janeiro: Rocco, 1998.

MIGUEL, A.; GARNICA, A. V. M.; IGLIORI, S. B. C.; D’AMBROSIO, U. Educação Matemática: breve histórico, ações implementadas e questões sobre sua disciplinarização. Revista Brasileira de Educação, Rio de Janeiro, v. 27, p. 70-93, 2004.

OLIVEIRA, V. C. A. Sobre a produção de significados para a noção de transformação linear em Álgebra Linear. 2002. 187p. Dissertação (Mestrado em Educação Matemática) - Instituto de Geociências e Ciências Exatas, Universidade Estadual Paulista, Rio Claro.

OLIVEIRA, V. C. A. Uma leitura sobre formação continuada de professores de matemática fundamentada em uma categoria da vida cotidiana. 2011. Tese (Doutorado em Educação Matemática) - Instituto de Geociências e Ciências Exatas, Universidade Estadual Paulista, Rio Claro. 2011.

ROLKOUSKI, E. Vida de professores de matemática - (im)possibilidades de leitura. 2006. 298p. Tese (Doutorado em Educação Matemática) - Instituto de Geociências e Ciências Exatas, Universidade Estadual Paulista, Rio Claro, 2006.

SILVA, A. M. Sobre a dinâmica da produção de significados para a Matemática. 2003. 244p. Tese (Doutorado em Educação Matemática) - Instituto de Geociências e Ciências Exatas, Universidade Estadual Paulista, Rio Claro, 2003.

SILVA, H. Centro de Educação Matemática (CEM): fragmentos de identidade. 2007. 448 f. Tese (Doutorado em Educação Matemática) - Instituto de Geociências e Ciências Exatas, Universidade Estadual Paulista, Rio Claro, 2007. 
SOUZA, L. A. História oral e educação matemática : um estudo, um grupo, uma compreensão a partir de várias versões. 2006. 313 p. Dissertação (Mestrado em Educação Matemática) - Instituto de Geociências e Ciências Exatas, Universidade Estadual Paulista, Rio Claro, 2006.

SOUZA, L. A.; CURY, F. G.; SILVA, H. Narrativas: um Olhar sobre o Exercício Historiográfico na Educação Matemática. In: CONGRESSO IBERO-AMERICANO DE HISTÓRIA DA EDUCAÇÃO MATEMÁTICA, 1., 2011, Covilhã. Anais... Covilhã: APM, 2011. P. 1-11.

VIOLA DOS SANTOS, J. R. Legitimidades possíveis para a Formação Matemática de Professores de Matemática (Ou: Assim falaram Zaratustras: uma tese para todos e para ninguém). 2012. 355 f. Tese (Doutorado em Educação Matemática) - Instituto de Geociências e Ciências Exatas, Universidade Estadual Paulista, Rio Claro, 2012.

Submetido em Junho de 2014. Aprovado em Janeiro de 2015. 